UMR 5824

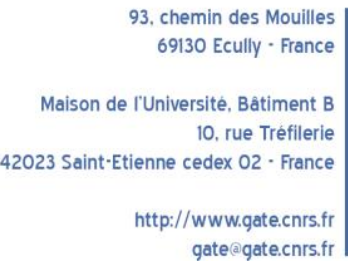

\title{
Rebalancing in China: a taxation approach
}

\section{Damien Cubizol}

\begin{abstract}
:
The rebalancing of the Chinese economy is analyzed through a heterogeneous taxation of various types of firms. Based on a two-country dynamic general equilibrium model, the paper applies tax reforms to raise consumption, reduce some firms' overinvestment (overcapacities) and maintain a high level of welfare.

To rebalance consumption and investment, taxation may allow reallocating a part of the labor force to firms that are not overinvesting. Moreover, the correction of distortions in production factor costs (capital and labor) is necessary during certain reforms applied in the model; that is, on the one hand, higher credit costs for firms that face soft budget constraints (via financial transactions taxes) and, on the other hand, a catch-up of foreign firms' wages by domestic firms (via business taxes and social security contributions).

These tax reforms bring welfare bene_ts to households and stabilize the welfare reaction to productivity shocks. Another interesting result is that in this framework, the rebalancing of the domestic demand in China does not require the readjustment of the external financial position. Indeed, the aggregate savings rate remains high and the supply of domestic assets is reduced.

Finally, a second theoretical framework proposes a heterogeneous taxation of consumption across home and foreign goods to enhance consumption.
\end{abstract}

\section{Keywords:}

The Chinese economy, tax reforms, financial intermediation, consumption, investment, welfare, foreign assets

\section{JEL codes:}

E20, F20, F30, H20, H30, P20, P30

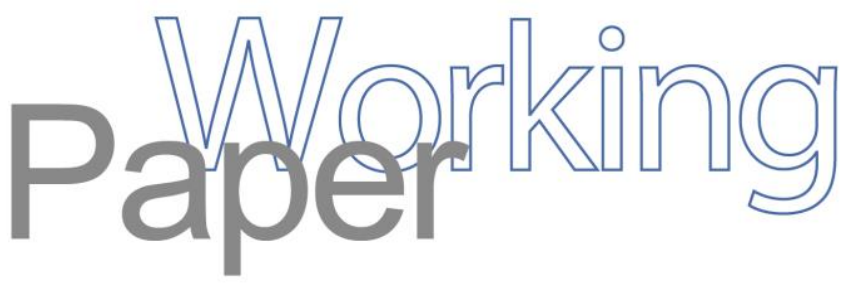




\title{
Rebalancing in China: a taxation approach*
}

\author{
Damien Cubizol ${ }^{\dagger}$
}

This version: December 2018

\begin{abstract}
The rebalancing of the Chinese economy is analyzed through a heterogeneous taxation of various types of firms. Based on a two-country dynamic general equilibrium model, the paper applies tax reforms to raise consumption, reduce some firms' overinvestment (overcapacities) and maintain a high level of welfare.

To rebalance consumption and investment, taxation may allow reallocating a part of the labor force to firms that are not overinvesting (via business taxes and social security contributions). Moreover, the correction of distortions in production factor costs (capital and labor) is necessary during certain reforms applied in the model; that is, on the one hand, higher credit costs for firms that face soft budget constraints (via financial transactions taxes) and, on the other hand, a catch-up of foreign firms' wages by domestic firms (via social security contributions).

These tax reforms bring welfare benefits to households and stabilize the welfare reaction to productivity shocks. Another interesting result is that in this framework, the rebalancing of the domestic demand in China does not require the readjustment of the external financial position. Indeed, the aggregate savings rate remains high and the supply of domestic assets is reduced.

Finally, another model proposes a heterogeneous taxation of consumption across home and foreign goods to enhance consumption.
\end{abstract}

Keywords: The Chinese economy, tax reforms, consumption, investment, welfare, financial intermediation and foreign assets.

JEL Classification: E20, F20, F30, H20, H30, P20, P30.

\footnotetext{
*I am very gratefull to Aurélien Eyquem for help and advices, and I thank Stéphane Auray, Sylvie Démurger, Gilles Dufrénot, Ludovic Gauvin, Jérôme Héricourt, Kun Li, Chu-Ping Lo, Johannes Pfeifer and Li Shi. I also thank seminar participants at Fordham University (CEF Conference 2017), Toulouse School of Economics (ADRES Conference 2017), HKUST ( $5^{\text {th }}$ ICCS Annual Meeting), CERDI ( $11^{\text {th }}$ International Conference on the Chinese Economy), Tsinghua University, University of Paris West (EconomiX) and Westminster Business School. I gratefully acknowledge research grants from the French Ministry of Education and Research and from Rhônes-Alpes region. All remaining errors are mine.

†Since September 2017: University Clermont Auvergne, CNRS, IRD, CERDI, F-63000 Clermont-Ferrand, France. Before September 2017: Sciences Po Toulouse, 2 Ter Rue des Puits Creuses, 31000 Toulouse. Also Univ Lyon, Université Lumière Lyon 2, GATE L-SE UMR 5824, F-69130 Ecully, France. Email: damien.cubizol@uca.fr.
} 


\section{Introduction}

The rebalancing of the Chinese economy is a widely debated topic, with regard to both the types of reforms and the method to establish them. This study uses a two-country dynamic general equilibrium model to address policy reforms relying on heterogeneous taxation across firms. The goal of this analysis is twofold.

First, the paper aims at establishing reforms that raise consumption (one priority of the Chinese government), reduce the huge investment rate of some firms (thus the induced overcapacities, debt dependency and financial instability), and increase the level of welfare (the requirement for social stability). Indeed, firms' investment rate is high in China (between $44 \%$ and $48 \%$ of GDP these last eight years ${ }^{1}$, and $24 \%$ for the world average, see Figure 1) and many Chinese firms have issues such as overcapacities, overindebtedness or even defaults (Fukumoto and Muto, 2011; Aglietta and Bai, 2012; Lee et al., 2012; Borst and Lardy, 2015; IMF, 2015; Artus, 2016a; Ding et al., 2016). Thus, one question can be raised: would a lower investment rate solve these issues? And would it be associated with welfare gains for households? Moreover, the consumption share is one of the lowest in the world (below $40 \%$ of GDP since $2004^{1}$, and $58.3 \%$ for the world average, see Figure 2) and China's growth is relying on foreign demand. Thus, the government aims at increasing consumption to have a growth that depends more on domestic demand and also to increase household welfare (with a higher purchasing power).

Second, the paper aims at taxing firms differently according to their production (with business/sales taxes), labor cost (with social security contributions) and access to credit (with financial transactions taxes). Indeed, Chinese firms are differentiated between SOEs, private domestic and foreign firms, with specific characteristics concerning initial technology, TFP growth, credit constraints, or capital share and depreciation. This firms' structure allows for a correction of the distortions in factor costs (labor and capital, see Aglietta and Bai, 2012) that lead to domestic and external imbalances. When the taxes are combined, SOEs' loan repayments increase and the wage differential between domestic and foreign firms is reduced. Thus, the initial better access to credit for SOEs (Boyreau-Debray, 2003; Dollar and Wei, 2007; Poncet et al., 2010; Song et al., 2011) is offsetted, and the wage gap between public, private and foreign firms in China (Chen et al., 2005; Yang et al., 2010; Chen et al., 2011; Hale and Long, 2011) is reduced. Moreover, these reforms also emphasize that a reallocation of the labor force (through social security contributions and business taxes) from firms with soft budget constraints to firms with hard budget constraints, to overcome overcapacity (which is due to overinvestment), is necessary to rebalance the economy. This reallocation is currently in progress in China but is a critical issue because of the large consequences on migration and employment (IMF, 2015; Artus, 2016a). This analysis also highlights the strong link between the rise in households' consumption and the decrease in firms' investment rate through financial intermediation during the reforms (the correlation between investment and household consumption can also be observed in the data during China's transition, see Figure 3). Indeed, the rise in firms' credit cost is a key channel because in addition to reduce firms' investment, it also increase returns on savings and thus household consumption in the model.

The tax reforms that are proposed in this paper have only a macroeconomic goal: reduce some firms overinvestment, increase the household consumption ratio, and maintain a high level of welfare, contrary to the 1994 tax reforms implemented in China. Indeed, one main goal of the 1994 tax reforms was to recentralize fiscal power to strengthen state control over local authorities (Wang, 1997; Aglietta and Bai, 2012). More precisely, the government aimed at stopping the decrease in both the ratio of government

\footnotetext{
${ }^{1}$ Source: World Bank database.
} 
revenue to GDP and the ratio of central to general government revenue (because the 1980s reform reduced the control over the local bureaucracy, despite the success of special economic zones for example).

This work is close to Bénassy-Quéré et al. (2013) but has different methods of rebalancing and taxing the economy. Indeed, Bénassy-Quéré et al. show that an improvement in China's social safety net can reduce global imbalances (regardless of the exchange-rate regime but requiring some relaxation of capital controls), and that the monetary reform is not so crucial. In our paper, the focus is on the heterogeneous structure of firms, with a larger set of taxes for reforms and a deeper welfare analysis. Our work is also in line with the descriptive study of Fukumoto and Muto (2011), who analyze the correction of distortions in the factor costs in China and highlight that external rebalancing is not necessary for domestic rebalancing. Indeed, on one hand, in our framework firms' profits and the household propensity to save remain large. On the other hand, after the reforms, the supply of domestic bonds is reduced because of firms' lower investment rates, increasing the purchases of foreign bonds. Therefore, the net foreign assets position remains high and can even increase. This work also deepens the welfare analysis of the Chinese rebalancing in the literature. It emphasizes that the tax reforms bring welfare benefits to households, by correcting distortions in lending and deposit rates, by increasing wages in specific firms, and thus by enhancing consumption. Finally, an extension of the model is developed, which includes nominal rigidities and heterogeneous taxes on the consumption of home and foreign goods during the reforms that increase the consumption share.

The model and its calibration are developed in the next section, and tax reforms are analyzed in section 3. The Appendix presents the model extension and the corresponding tax reforms.

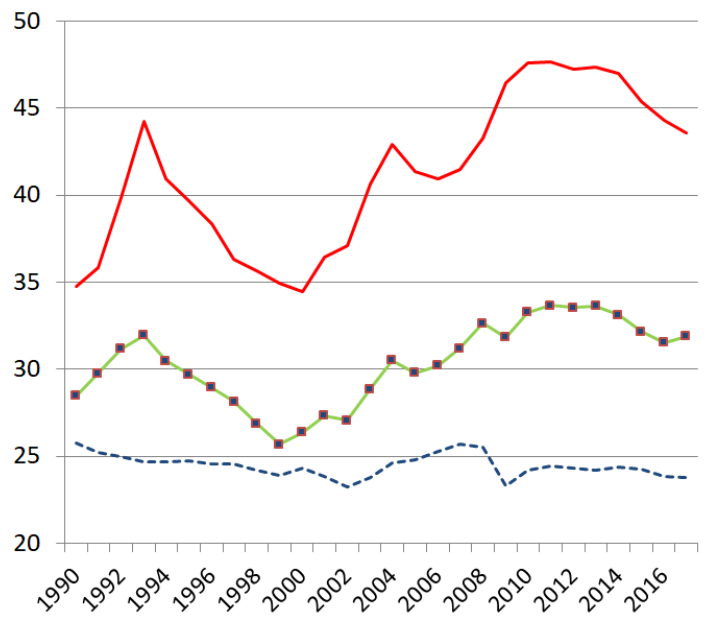

Figure 1: Investment rate (\% GDP) Source: World Bank database

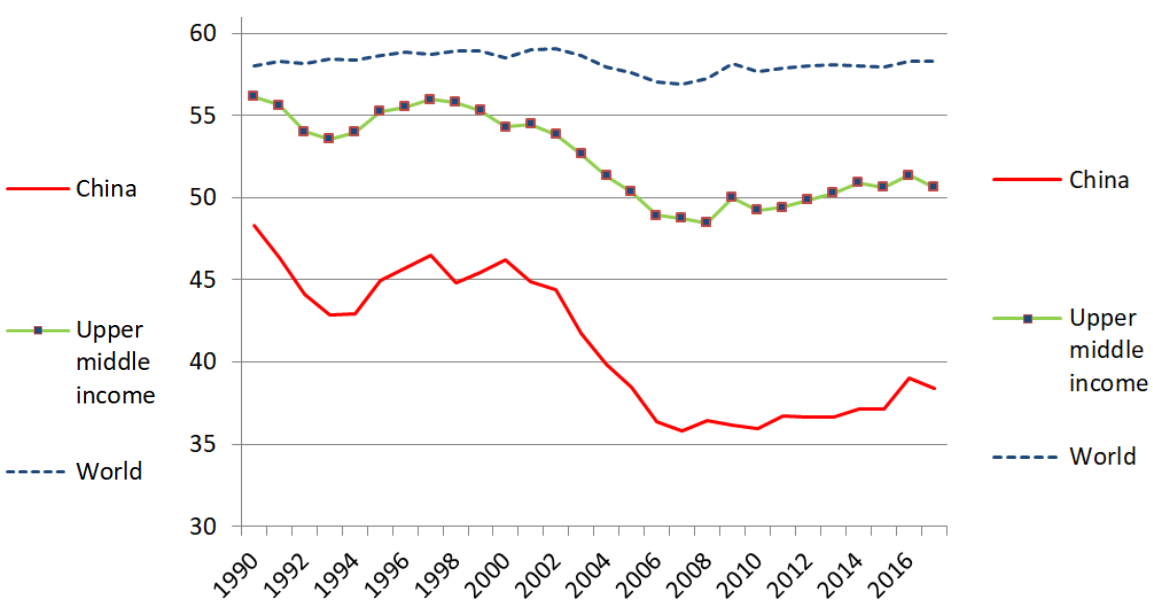

Figure 2: Consumption rate (\% GDP) Source: World Bank database

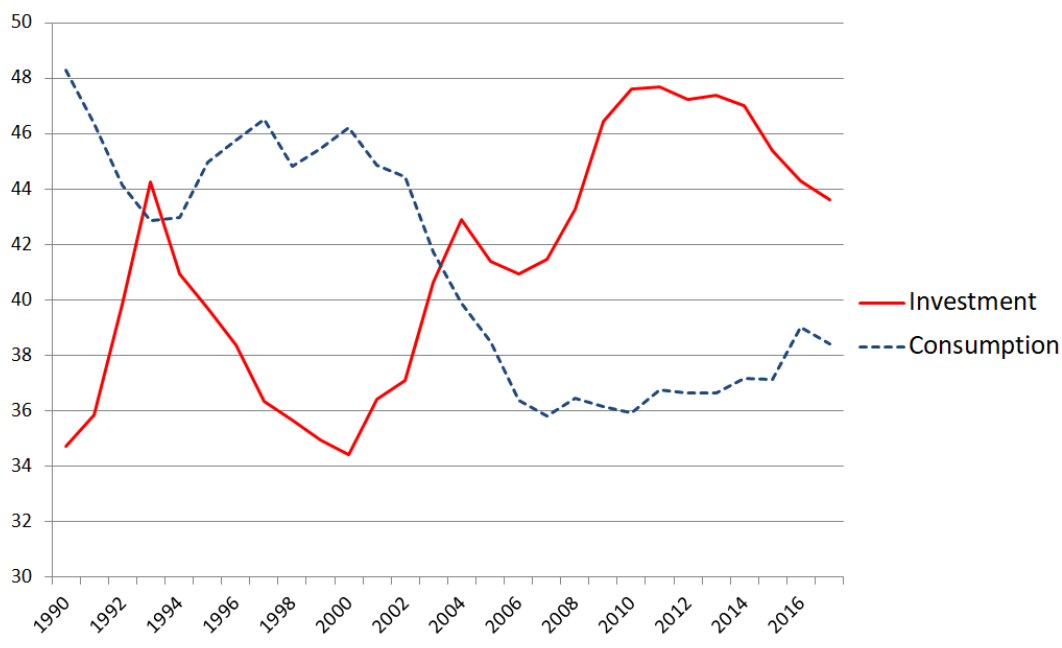

Figure 3: Consumption and investment rates in China (\% GDP) Source: World Bank database 


\section{The model}

A model of two large countries labeled $d$ (domestic) and $f$ (foreign) is built, with infinite horizon. To fit our issue and context, the domestic country is China and the foreign country is the rest of the world. Each country has households and firms. Households work, consume and save; their savings finance investments of domestic and foreign firms. ${ }^{2}$ Firms accumulate capital and use a share of their capital to produce abroad, which is assimilated to FDI. SOEs are added to private domestic and foreign firms. Firms are credit constrained and produce utilizing a standard Cobb-Douglas technology. TFP growth is considered to model growth differentials between China and the rest of the world. In China, SOEs have a slightly higher TFP growth ${ }^{3}$ (Hsieh and Song, 2015) and have better access to credit (credit constraints for SOEs are relaxed, making them capital-intensive whereas private firms remain labor-intensive, as in Song et al., 2011). This first model focuses on real factors and abstracts from nominal rigidities to keep the framework simple, so relative prices are assumed to be one. The nominal exchange rate cannot be considered without prices of goods, nominal rigidities, or value function for bonds prices. As for the real exchange rate, the relative marginal costs give an idea of its evolution. Finally, the model applies a calibration based on data from 2014 to 2017 (according to availability).

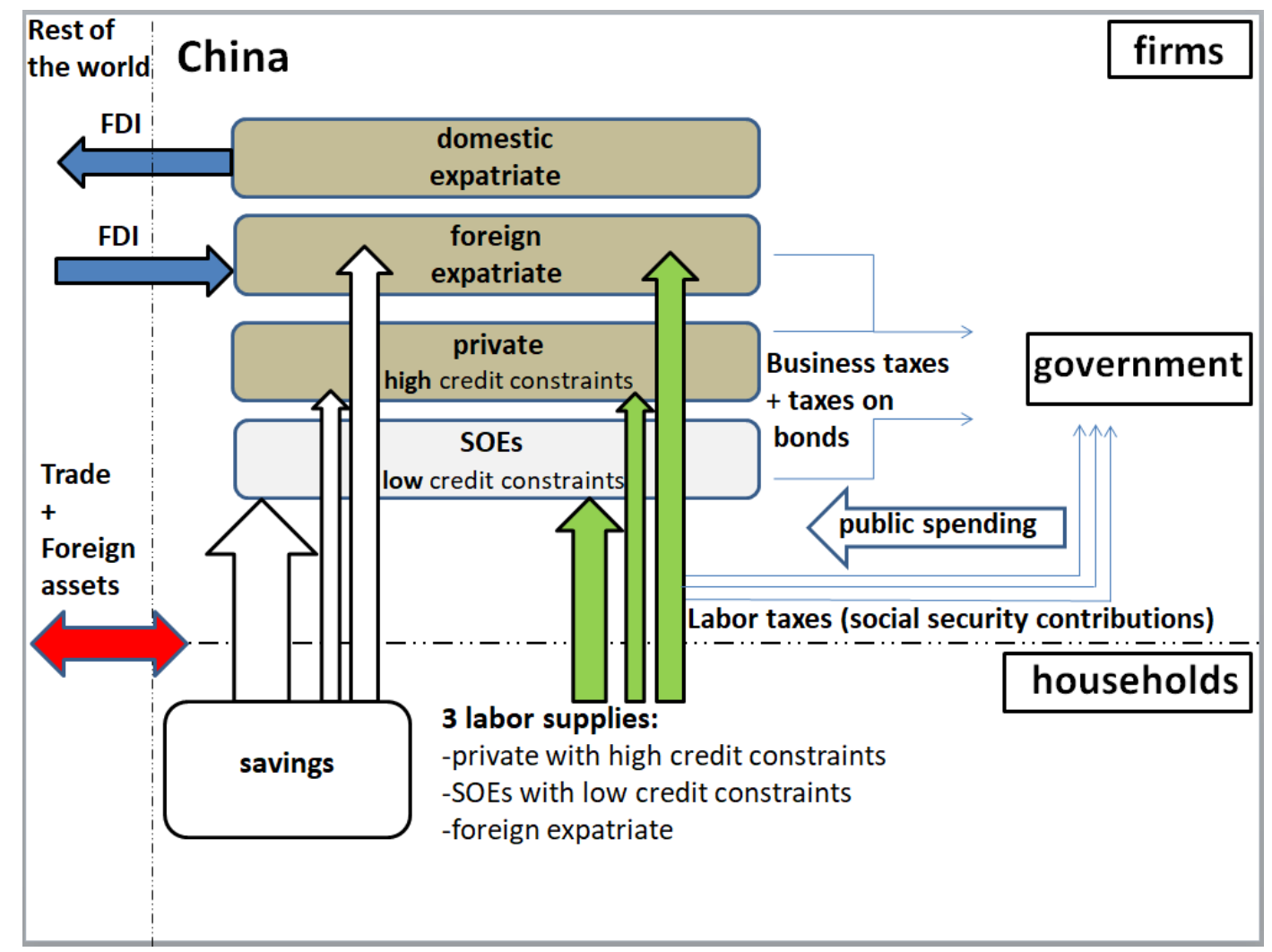

Figure 4: Diagram of the model

\footnotetext{
${ }^{2}$ Actually, a share of Chinese savings are invested in foreign bonds through foreign reserves and sovereign wealth funds, but it is not the main focus here. In the model this step is skipped to maintain a simple framework and it is assumed that household and corporate savings directly finance foreign firms (and of course domestic ones), as in Benhima (2013).

${ }^{3}$ According to Hsieh and Song (2015), there is a recent catch-up process of TFP growth by SOEs against private firms (particularly for large SOEs). However, SOEs' TFP level remains low against private firms (particularly against foreign firms).
} 


\subsection{Households}

Domestic households maximize a welfare index:

$$
\begin{cases}\operatorname{Max}_{0} \sum_{t=0}^{\infty} \beta_{d}^{t}\left(\frac{C_{d, t}^{1-\sigma}}{1-\sigma}-\frac{N_{S, t}^{1+\psi}+N_{d, t}^{1+\psi}+N_{f, t}^{* 1+\psi}}{1+\psi}\right) & \sigma \neq 1 \\ \operatorname{Max}_{0} \sum_{t=0}^{\infty} \beta_{d}^{t}\left(\log \left(C_{d, t}\right)-\frac{N_{S, t}^{1+\psi}+N_{d, t}^{1+\psi}+N_{f, t}^{* 1+\psi}}{1+\psi}\right) & \sigma=1 .\end{cases}
$$

subject to the budget constraint:

$$
\begin{array}{r}
C_{d, t}+B_{d, t}+B_{S, t}+\left[F B_{d, t}+\frac{\chi_{d}}{1+\mu_{d}}\left(F B_{d, t}-F B_{d, t-1}\right)^{1+\mu_{d}}\right]=\pi_{d, T, t}+W_{d, t} N_{d, t}+W_{S, t} N_{S, t}+W_{f, t}^{*} N_{f, t}^{*} \\
+\left(1+r_{f, t}\right)\left(\mathbf{1}-\gamma_{f}\right) F B_{d, t-1}+\left(1+r_{d, t}\right)\left[\left(\mathbf{1}-\gamma_{S}\right) B_{S, t-1}+\left(\mathbf{1}-\gamma_{d}\right) B_{d, t-1}\right]
\end{array}
$$

$\beta$ is the discount rate, $\psi$ the inverse of the Frisch elasticity of labor supply, and $\sigma$ the inverse of the intertemporal elasticity of substitution. $N_{d, t}\left(\operatorname{resp} . N_{f, t}^{*}\right)$ represents hours of work supplied by domestic households in the domestic firms (resp. foreign expatriate firms), $N_{S, t}$ labor supply in SOEs, and $C_{d, t}$ consumption.

Household incomes $\left(W_{d, t} N_{d, t}\right.$ from domestic firm, $W_{f, t}^{*} N_{f, t}^{*}$ from foreign expatriate firms, and $W_{S, t} N_{S, t}$ from SOEs) are partly consumed in a single good and saved utilizing bonds. Household savings finance firms, thus, households can choose between bonds issued by firms of country $d$ ( $B_{d, t}$ for private firms, $B_{S, t}$ for SOEs) and foreign bonds $\left(F B_{d, t}\right)$, considering that financial markets are incomplete. Various degrees of financial integration are modeled with varying trading costs on the purchase of foreign bonds $\frac{\chi_{d}}{1+\mu}\left(F B_{d, t}-F B_{d, t-1}\right)^{1+\mu}$; these costs are a proxy for capital controls. Parameter $\chi_{d}$ controls for the magnitude of costs and $\mu$ for their curvature. ${ }^{4}$

In Equation (37), $r_{d / f, t}$ are domestic and foreign real interest rates, and $\pi_{d, T, t}$ are profits paid by firms (because firms belong to households).

Taxation. $\gamma_{d / f / S}$ are taxes on firms' loan repayments, which also affects households' returns on bonds. It is equivalent to financial transactions taxes.

First ordinary conditions are:

$$
\begin{aligned}
N_{d, t} & =\left[W_{d, t} C_{d, t}^{-\sigma}\right]^{\frac{1}{\psi}} \\
N_{f, t}^{*} & =\left[W_{f, t}^{*} C_{d, t}^{-\sigma}\right]^{\frac{1}{\psi}} \\
N_{S, t} & =\left[W_{S, t} C_{d, t}^{-\sigma}\right]^{\frac{1}{\psi}} \\
C_{d, t}^{-\sigma} & =\beta E_{t}\left[C_{d, t+1}^{-\sigma}\left(1+r_{d, t+1}\right)\left(\mathbf{1}-\gamma_{d / S}\right)\right] \\
\lambda_{d, t}\left[1+\chi_{d}\left(F B_{d, t}-F B_{d, t-1}\right)^{\mu_{d}}\right] & =\beta E_{t}\left[\lambda_{d, t+1}\left(1+r_{f, t+1}\right)\left(1-\gamma_{f}\right)\right]
\end{aligned}
$$

Equations (2), (3) and (4) are the labor supplies of households to firms, and Equation 5 is the usual

\footnotetext{
${ }^{4}$ Chinese financial integration is more complex. Indeed, there are various restrictions and taxes on financial capital movements depending on the direction and type of financial capital, and it was varying during the transition (Kimball and Xiao, 2006, and the Annual Report of Exchange Arrangements and Exchange Restrictions (AREAER)). Note that trading costs are based on new bonds' purchase at time $t$ and not on the divergence from the steady state. Indeed, deterministic simulations are conducted and the transition changes the steady state. With stochastic shocks, trading costs should be: $\frac{\chi_{d}}{1+\mu}\left(F B_{d, t}^{*}-\overline{F B_{d}^{*}}\right)^{1+\mu}$
} 
Euler equation. Although there are important frictions on the Chinese labor market, for simplicity the latter is modeled as competitive and frictionless because such frictions would only change the speed and magnitude of reallocation and the evolution of wages, but not the qualitative behavior of all variables. ${ }^{5}$ By combining Equations (5) and (6), the trade-off between domestic and foreign bonds is obtained, once the amount of domestic bonds is fixed through firms' credit constraints (more details are in the subsection on firms).

$$
E_{t}\left[\frac{\left(1+r_{d, t+1}\right)\left(1-\gamma_{d / S}\right)\left(1+\chi_{d}\left(F B_{d, t}-F B_{d, t-1}\right)^{\mu_{d}}\right)}{\left(1+r_{f, t+1}\right)\left(1-\gamma_{f}\right)}-1\right]=0
$$

China buys foreign bonds $F B_{d, t}$ (resp. become indebted to the rest of the world) when returns on foreign bonds are higher (resp. lower) than those on domestic bonds:

$$
\left(1+r_{f, t+1}\right)\left(1-\gamma_{f}\right)>\left(1+r_{d, t+1}\right)\left(1-\gamma_{d / S}\right)\left[1+\chi_{d}\left(F B_{d, t}-F B_{d, t-1}\right)^{\mu_{d}}\right] .
$$

Foreign households solve the same problem but the amount of foreign bonds purchases (Chinese foreign liabilities, $F B_{f, t}$ ) remains constant because of capital controls in China. ${ }^{6}$

The list of all variables is in Table 1 .

\subsection{Firms}

The population of firms comprises private domestic firms, private foreign firms and SOEs.

Domestic firms accumulate capital, produce, and maximize their stream of profits:

$$
\max E_{0} \sum_{t=0}^{\infty} \beta^{t} \lambda_{d, t} \pi_{d, T, t}
$$

with

$$
\begin{array}{r}
\pi_{d, T, t}=\pi_{d, t}+\pi_{d, t}^{*}+\pi_{S, t}=Y_{d, t}\left(\mathbf{1}-\boldsymbol{\tau}_{\boldsymbol{y} d}\right)+Y_{d, t}^{*}\left(\mathbf{1}-\boldsymbol{\tau}_{\boldsymbol{y}_{d^{*}}}\right)+Y_{S, t}\left(\mathbf{1}-\boldsymbol{\tau}_{\boldsymbol{y}_{S}}\right) \\
+D_{d, t}-\left(1+r_{d, t}\right)\left(\mathbf{1}-\gamma_{\boldsymbol{d}}\right) D_{d, t-1}+D_{d, t}^{*}-\left(1+r_{f, t}\right)\left(\mathbf{1}-\gamma_{\boldsymbol{f}}\right) D_{d, t-1}^{*}+D_{S, t}-\left(1+r_{d, t}\right)\left(\mathbf{1}-\gamma_{S}\right) D_{S, t-1} \\
-\left(W_{d, t} N_{d, t}\left(\mathbf{1}+\boldsymbol{\tau}_{\boldsymbol{w}_{d}}\right)+I_{d, t}\right)-\left(W_{d, t}^{*} N_{d, t}^{*}\left(\mathbf{1}+\boldsymbol{\tau}_{\boldsymbol{w}_{d}^{*}}\right)+I_{d, t}^{*}\right)-\left(W_{S, t} N_{S, t}\left(\mathbf{1}+\boldsymbol{\tau}_{\boldsymbol{w}_{s}}\right)+I_{S, t}\right)
\end{array}
$$

Firms operate in both countries because a share of their capital is expatriated to produce abroad: it is equivalent to investing in the foreign country through FDI. $\pi_{d, T, t}$ represents the total profits of domestic firms, $\pi_{d, t}$ (resp. $\pi_{d, t}^{*}$ ) the profits of the capital invested locally (resp. abroad) by private domestic firms, and $\pi_{S, t}$ the profits of SOEs.

When expatriated, firms have their home country's initial level of TFP and share of capital in production, but the TFP growth, labor force, capital depreciation and funding are from the host (that is, local) country. Indeed, according to Du and Girma (2007), foreign firms in China were equally financed by the home and host countries' financial intermediation during the transition. ${ }^{7}$

\footnotetext{
${ }^{5}$ Zuo and Wang (1999) explain that despite the huge flow of rural migrants to cities that followed reforms during the transition, the access of rural migrants to urban labor markets is selective (Hukou system). Even if these restrictions on migrations were still present in the second part of the transition, they were considerably reduced (Wang, 2004).

${ }^{6}$ The value is fixed at $14 \%$ of GDP (CEIC Data, 2017).

${ }^{7}$ Feldstein (2000), Harrison and McMillan (2003), and Alfaro et al. (2009) also mention the role of the local credit market on FDI determinants.
} 
Production and technology. Production combines labor and capital through Cobb-Douglas technology:

$$
\begin{aligned}
& Y_{d, t}=A_{d, t} \cdot K_{d, t-1}^{\alpha_{d}} N_{d, t}^{1-\alpha_{d}} \\
& Y_{d, t}^{*}=A_{d^{*}, t} \cdot K_{d^{*}, t-1}^{\alpha_{d}} N_{d^{*}, t}^{1-\alpha_{d}} \\
& Y_{S, t}=A_{S, t} \cdot K_{S, t-1}^{\alpha_{S}} N_{S, t}^{1-\alpha_{S}}
\end{aligned}
$$

where $Y_{d, t}$ is the production of a domestic firm locally, $Y_{d, t}^{*}$ the production of a domestic firm abroad, and $Y_{S, t}$ the production of SOEs. The technology parameter $A_{t}$ grows at an exogenous rate $g_{A}$ : $A_{t}=$ $\left(1+g_{A}\right) A_{t-1}=\left(1+g_{A}\right)^{t} A_{0} \cdot g_{A_{d}}>g_{A_{f}}$ to have a larger TFP growth in China than in the rest of the world. TFP growth and the initial TFP are not similar across firms in China: domestic private firms have a higher initial TFP than SOEs $\left(A_{d, 0}>A_{S, 0}\right)$, but SOEs have a higher TFP growth $\left(g_{A_{S}}>g_{A_{d}}\right) .^{3}$ As described above, the initial level of technology of expatriate firms is from the home country; thus, foreign firms in China have a higher initial technology level than domestic firms $\left(A_{f^{*}, 0}>A_{d, 0}\right)$ but have the same TFP growth.

Balanced growth. The model is solved along the balanced growth path to have stationarity: except interest rates and hours worked, each variable is computed against $A_{t}$ to deflate by the state of technology. ${ }^{8}$

Taxation. The government levies taxes on the three types of labor cost $\left(\tau_{w_{d}}, \tau_{w_{d_{*}}}\right.$ and $\left.\tau_{w_{s}}\right)$. These taxes can be considered as directly paid by the firm as social security contributions (and they can take distinct values across different types of firms during the reforms). Then, $\gamma$ is used as a financial transactions tax to reduce returns on household bonds and loan repayments by firms. This tax enables the government to compensate any difference in the credit constraints between the different types of firms during the reform (then, the interest rate is naturally adjusted in the second steady state).

Finally, taxes are levied by the government on firms' production $\left(\tau_{y_{d}}, \tau_{y_{d^{*}}}\right.$, and $\tau_{y_{s}}$; in the data these taxes are equivalent to business or sales taxes). These taxes can take different values across firms. We select taxes on firms' production and not taxes on firms' profits as instruments, because taxes on firms' production have a greater range of variation between private and public sectors. Indeed, the latter vary between sectors (such as construction, industry and agriculture) and between SOEs and private firms. ${ }^{9}$ Moreover, these taxes are much lower than taxes on profits, therefore, a large increase in their value could still be affordable.

Investment. Convex adjustment costs $\Phi_{I}$ on investment are added in the capital accumulation process (Christiano et al., 2005; Groth and Khan, 2010; Albonico et al., 2012) to limit excessively large adjustments in the first periods of the reform. Thus, the accumulation of capital in Chinese firms $d, d^{*}$ and $S$ has the following law of motion: ${ }^{10}$

$$
K_{d, d^{*}, S_{t}}=\left(1-\delta_{d, f, S}\right) K_{d, d^{*}, S_{t-1}}+I_{d, d^{*}, S_{t}}+I_{d, d^{*}, S_{t-1}} \Phi_{I}\left[\frac{I_{d, d^{*}, S_{t}}}{I_{d, d^{*}, S_{t-1}}}-1\right]^{2}
$$

${ }^{8}$ For example, $Y_{d, t}^{*}$ and the dynamic of expatriate capital become $y_{d, t}^{*}=\frac{Y_{d, t}^{*}}{A_{d, t}^{*}}$ and $k_{d, t}^{*}=\left(1-\delta_{f}\right) \frac{K_{d, t-1}^{*}}{A_{d, t-1}^{*}} \cdot \frac{A_{d, t-1}^{*}}{A_{d, t}^{*}}+$ $\frac{I_{d, t}^{*}}{A_{d, t}^{*}}=\left(1-\delta_{f}\right) \frac{k_{d, t-1}^{*}}{1+g_{A_{f}}}+i_{d, t}^{*}$, with $A_{d, t}^{*}=\left(1+g_{A_{f}}\right)^{t} A_{d, 0}$ for expatriate firms.

${ }^{9}$ According to China Statistical Yearbook database, the ratio of "tax and extra charge from principal business" over "revenue of principal business" was, for example, equal to $6.68 \%$ in construction, $2.21 \%$ in industry and $0.5 \%$ in trade and whole sale sectors ("tax and extra charges from principal business" can refer to sales taxes; Source: CSY).

${ }^{10}$ Along the balanced growth path, the accumulation of capital becomes (for the three types of firms $d, d^{*}$ and $S$ ):

$$
k_{d, d^{*}, S_{t}}=\left(1-\delta_{d, f, S}\right) \frac{k_{d, d^{*}, S_{t-1}}}{1+g_{A_{d, f, S}}}+i_{d, d^{*}, S_{t}}+\frac{i_{d, d^{*}, S_{t-1}}}{1+g_{A_{d, f, S}}} \Phi_{I}\left[\left(1+g_{A_{d, f, S}}\right) \frac{i_{d, d^{*}, S_{t}}}{i_{d, d^{*}, S_{t-1}}}-1\right]^{2}
$$


where $K_{d, t}^{*}$ and $I_{d, t}^{*}$ are domestic capital and investment expatriated in the foreign country to produce $Y_{d, t}^{*}$. Capital depreciates at each period with a rate $\delta\left(\delta_{d}\right.$ for private domestic capital, $\delta_{f}$ for private expatriate capital, and $\delta_{S}$ for state-owned capital).

Debt and credit constraints. Firms can borrow additional capital. The total amount of deposits available in banks to lend to firms is the addition of household domestic savings (the purchase of domestic bonds, $B_{d, t}$ and $\left.B_{S, t}\right)$ and the purchase of bonds by the foreign country: $D_{d, T, t}=B_{d, t}+B_{S, t}+F B_{f, t}$ in China, $D_{f, T, t}=B_{f, t}+F B_{d, t}$ in the rest of the world. $B_{d, t}$ comprises bonds for private domestic and foreign firms, $B_{S, t}$ are bonds for SOEs. Then, total deposits are proportionally distributed between firms according to their capital size, and credit reimbursement varies between firms because of parameter $\gamma{ }^{11}$ The amount of purchases of foreign bonds is determined by Equation (7) in China, and the amount of domestic bonds is determined with borrowing constraints $\zeta$ faced by firms:

$$
\begin{aligned}
B_{d, t} & =\zeta_{d}\left(K_{d, t}+K_{f, t}^{*}\right) \\
B_{S, t} & =\zeta_{S} K_{S, t}
\end{aligned}
$$

$\zeta_{S}>\zeta_{d}$ because there are tighter credit constraints for private firms than for SOEs (Boyreau-Debray, 2003; Boyreau-Debray and Wei, 2005; Dollar and Wei, 2007; Poncet et al., 2010; Song et al., 2011). To bypass these credit constraints some private firms use FDI (Héricourt and Poncet, 2009; Ju and Wei, 2010; Poncet et al., 2010) or shadow banking (Tsai, 2002; Krugman, 2011; Li, 2014; Funke et al., 2015). These are not modeled here to maintain a simple framework. As explained above, firms' domestic branches borrow in the country of origin, whereas their expatriate branches borrow abroad (Du and Girma, 2007). First order conditions imply:

$$
\begin{aligned}
& \left(1-\alpha_{d}\right) \frac{Y_{d, t}}{N_{d, t}}\left(\mathbf{1}-\boldsymbol{\tau}_{\boldsymbol{y} d}\right)=W_{d, t}\left(\mathbf{1}+\boldsymbol{\tau}_{\boldsymbol{w}_{d}}\right) \\
& \left(1-\alpha_{d}\right) \frac{Y_{d, t}^{*}}{N_{d, t}^{*}}\left(1-\tau_{y_{d^{*}}}\right)=W_{d, t}^{*}\left(1+\tau_{w_{d}^{*}}\right) \\
& \left(1-\alpha_{S}\right) \frac{Y_{S, t}}{N_{S, t}}\left(\mathbf{1}-\tau_{y s}\right)=W_{S, t}\left(\mathbf{1}+\boldsymbol{\tau}_{\boldsymbol{w} s}\right) \\
& E_{t}\left[\frac{\lambda_{d, t+1}}{\lambda_{d, t}}\left(1-\delta_{d}+\alpha_{d} \frac{Y_{d, t+1}}{K_{d, t}}\left(\mathbf{1}-\boldsymbol{\tau}_{y d}\right)-\zeta_{d}\left(1+r_{d, t}\right)\left(\mathbf{1}-\gamma_{d}\right)\right)-\left(\frac{1-\zeta_{d}}{\beta}\right)\right]=0 \\
& E_{t}\left[\frac{\lambda_{d, t+1}}{\lambda_{d, t}}\left(1-\delta_{f}+\alpha_{d} \frac{Y_{d, t+1}^{*}}{K_{d, t}^{*}}\left(\mathbf{1}-\boldsymbol{\tau}_{y_{d^{*}}}\right)-\zeta_{f}\left(1+r_{f, t}\right)\left(\mathbf{1}-\gamma_{f}\right)\right)-\left(\frac{1-\zeta_{f}}{\beta}\right)\right]=0 \\
& E_{t}\left[\frac{\lambda_{d, t+1}}{\lambda_{d, t}}\left(1-\delta_{S}+\alpha_{S} \frac{Y_{S, t+1}}{K_{S, t}}\left(\mathbf{1}-\boldsymbol{\tau}_{y s}\right)-\zeta_{S}\left(1+r_{d, t}\right)\left(\mathbf{1}-\gamma_{S}\right)\right)-\left(\frac{1-\zeta_{S}}{\beta}\right)\right]=0
\end{aligned}
$$

Equations (16), (17) and (18) are standard labor demands, and Equations (19), (20) and (21) capture the marginal returns on investment. Firms have the choice to invest in either the domestic country or the foreign country; thus, the share of capital invested abroad depends on the marginal product of capital compared to credit costs. The former depends on the initial technology, TFP growth, the capital and labor shares, and capital depreciation, whereas credit costs depend on the real interest rate, the tightness of credit constraints, and moral hazard. A firm makes the choice to invest fixed capital abroad when

\footnotetext{
${ }^{11}$ Total deposits' distribution to each type of firms is $D_{d, t}=\left(\frac{K_{d, t}}{K_{d, t}+K_{f, t}^{*}+K_{S, t}}\right) D_{d, T, t}, \quad D_{f, t}^{*}=$ $\left(\frac{K_{f, t}^{*}}{K_{d, t}+K_{f, t}^{*}+K_{S, t}}\right) D_{d, T, t}$, and $D_{S, t}=\left(\frac{K_{S, t}}{K_{d, t}+K_{f, t}^{*}+K_{S, t}}\right) D_{d, T, t}$. Credit reimbursement is $\left(1+r_{d, t}\right)\left(1-\gamma_{d}\right)$ for private firms and $\left(1+r_{d, t}\right)\left(1-\gamma_{S}\right)$ for SOEs.
} 
$1-\delta_{f}+\alpha_{d} \frac{Y_{d, t+1}^{*}}{K_{d, t}^{*}}-\zeta_{f}\left(1+r_{f, t}\right)\left(1-\gamma_{f}\right)$ is larger than $1-\delta_{d}+\alpha_{d} \frac{Y_{d, t+1}}{K_{d, t}}-\zeta_{d}\left(1+r_{d, t}\right)\left(1-\gamma_{d}\right) .{ }^{12}$

Lastly, in this type of model firms belong to households. Therefore, firms' profits are saved or not by households (who can potentially buy financial assets (bonds) abroad following the trade-off in Equation 7).

Foreign firms solve the same problem with similar equations for their domestic and expatriate private firms but without SOEs. Under the following calibration, $F B_{d, t}>0$ : there are purchases of foreign bonds by China in Equation (7); thus, firms in the foreign country are indebted to China. It is equivalent to the external financial deficit of the U.S. for example. Note that Equations (17) and (20) are valid for domestic firms operating abroad. The foreign firms operating in China have the following labor demand and marginal returns on investments:

$$
\begin{aligned}
\left(1-\alpha_{f}\right) \frac{Y_{f, t}^{*}}{N_{f, t}^{*}}\left(\mathbf{1}-\boldsymbol{\tau}_{\boldsymbol{y}_{f^{*}}}\right) & =W_{f, t}^{*}\left(\mathbf{1}+\boldsymbol{\tau}_{\boldsymbol{w}_{f}^{*}}\right)(25) \\
E_{t}\left[\frac{\lambda_{f, t+1}}{\lambda_{f, t}}\left(1-\delta_{d}+\alpha_{f} \frac{Y_{f, t+1}^{*}}{K_{f, t}^{*}}\left(\mathbf{1}-\boldsymbol{\tau}_{\boldsymbol{y}_{f^{*}}}\right)-\zeta_{d}\left(1+r_{d, t}\right)\left(\mathbf{1}-\gamma_{f^{*}}\right)\right)-\left(\frac{1-\zeta_{d}}{\beta}\right)\right] & =0
\end{aligned}
$$

with $Y_{f, t}^{*}=A_{f^{*}, t} \cdot K_{f^{*}, t-1}^{\alpha_{f}} N_{f^{*}, t}^{1-\alpha_{f}}$ and $A_{f^{*}, t}=\left(1+g_{A_{d}}\right)^{t} A_{f, 0}$. Their capital share and initial level of technology remain national while their funding, TFP growth, labor force and capital depreciation are local.

The list of all variables is in Table 1.

\subsection{Government and aggregation}

Both domestic and foreign governments collect their revenue from firms' labor costs and production, and from financial transactions; for simplicity and because there are already many different types of bonds, it is assumed that the government does not use domestic or foreign bonds to finance potential deficits. ${ }^{13}$

$$
\begin{array}{r}
G_{d, t}=\tau_{y_{d}} Y_{d, t}+\tau_{y_{f} *} Y_{f^{*}, t}+\tau_{y_{S}} Y_{S, t}+\tau_{w_{d}} W_{d, t} N_{d, t}+\tau_{w_{f^{*}}} W_{f^{*}, t} N_{f^{*}, t}+\tau_{y_{S}} W_{S, t} N_{S, t} \\
+\gamma_{d}\left(1+r_{d, t}\right)\left(B_{d, t}+F B_{f, t}\right)+\gamma_{S}\left(1+r_{d, t}\right) B_{S, t} \\
G_{f, t}=\tau_{y_{f}} Y_{f, t}+\tau_{y_{d^{*}}} Y_{d^{*}, t}+\tau_{y_{S_{f}}} Y_{S_{f}, t}+ \\
\tau_{w_{f}} W_{f, t} N_{f, t}+\tau_{w_{d^{*}}} W_{d^{*}, t} N_{d^{*}, t}+\tau_{y_{S_{f}}} W_{S_{f}, t} N_{S_{f}, t} \\
+\gamma_{f}\left(1+r_{f, t}\right)\left(B_{f, t}+F B_{d, t}\right)+\gamma_{S_{f}}\left(1+r_{f, t}\right) B_{S_{f}, t}
\end{array}
$$

${ }^{12}$ Along the balanced growth path, marginal returns on investments are:

$$
\begin{aligned}
m R_{I_{d, t}} & =\left[\alpha_{d} \frac{y_{d, t+1}}{k_{d, t}}\left(1+g_{A_{d}}\right)\left(\mathbf{1}-\boldsymbol{\tau}_{\boldsymbol{y} \boldsymbol{d}}\right)+\left(1-\delta_{d}-\zeta_{d}\left(1+r_{d, t}\right)\left(\mathbf{1}-\boldsymbol{\gamma}_{\boldsymbol{d}}\right)\right)\right]-\left(\frac{1-\zeta_{d}}{\beta}\right) \\
m R_{I_{d^{*}, t}} & =\left[\alpha_{d} \frac{y_{d, t+1}^{*}}{k_{d, t}^{*}}\left(1+g_{A_{f}}\right)\left(\mathbf{1}-\boldsymbol{\tau}_{\boldsymbol{y} \boldsymbol{d}^{*}}\right)+\left(1-\delta_{f}-\zeta_{f}\left(1+r_{f, t}\right)\left(\mathbf{1}-\boldsymbol{\gamma}_{\boldsymbol{f}}\right)\right)\right]-\left(\frac{1-\zeta_{f}}{\beta}\right) \\
m R_{I_{S, t}} & =\left[\alpha_{S} \frac{y_{S, t+1}}{k_{S, t}}\left(1+g_{A_{S}}\right)\left(\mathbf{1}-\boldsymbol{\tau}_{\boldsymbol{y} S}\right)+\left(1-\delta_{S}-\zeta_{S}\left(1+r_{d, t}\right)\left(\mathbf{1}-\boldsymbol{\gamma}_{\boldsymbol{S}}\right)\right)\right]-\left(\frac{1-\zeta_{S}}{\beta}\right)
\end{aligned}
$$

${ }^{13}$ The concern of the level of the sovereign debt is not crucial in China because there is no external financial dependency. Still concerning the modeling of fiscal policy, this tax reform focuses on macroeconomic reforms but not on decentralization issues. 
Then, the government uses fiscal receipts to finance public expenditure on the goods and services market:

$$
\begin{array}{r}
Y_{d, t}+Y_{f, t}^{*}+Y_{S, t}+Y_{f, t}+Y_{d, t}^{*}+Y_{S_{f}, t}=C_{d, t}+C_{f, t}+G_{d, t}+G_{f, t}+I_{d, t}+I_{f, t}+I_{d, t}^{*} \\
+I_{f, t}^{*}+I_{S, t}+I_{S_{f}, t}+\frac{\chi_{f}}{1+\mu_{f}}\left(F B_{f, t}-F B_{f, t-1}\right)^{1+\mu_{f}}++\frac{\chi_{d}}{1+\mu_{d}}\left(F B_{d, t}-F B_{d, t-1}\right)^{1+\mu_{d}}
\end{array}
$$

Concerning labor market clearing conditions, they are already implicitly imbedded in the households section: total labor supply in the domestic country is $\left(N_{d, t}+N_{f, t}^{*}+N_{S, t}\right)$, and $\left(N_{f, t}+N_{d, t}^{*}+N_{S_{f}, t}\right)$ in the foreign country.

As explained in the previous subsection, bonds market clearing conditions are total deposits available in each country: the addition of household domestic savings and bonds purchases from abroad:

$$
\begin{aligned}
D_{d, T, t} & =B_{d, t}+B_{S, t}+F B_{f, t} \\
& =\zeta_{d}\left(K_{d, t}+K_{f, t}^{*}\right)+\zeta_{S} K_{S, t}+F B_{f, t} \\
D_{f, T, t} & =B_{f, t}+B_{S_{f}, t}+F B_{d, t} \\
& =\zeta_{f}\left(K_{f, t}+K_{d, t}^{*}\right)+\zeta_{S} K_{S_{f}, t}+F B_{d, t} .
\end{aligned}
$$

There is one firm of each type by country in the model. It is the aggregation of $n$ firms of type $d / f^{*} / S$ in the domestic country, and $m$ firms of type $f / d^{*} / S_{f}$ in the foreign country. Each type of firm has a share $s$ of employment in the total of firms; it is fixed at the steady state but evolves endogenously after. It corresponds to the share of SOEs and inward/outward FDI (coefficients $\eta_{\text {Soe }}, \eta_{\text {Soe }_{f}}, \omega_{\text {in }}$ and $\omega_{\text {out }}$ ). So for output, capital and investment, we get:

-with $s_{k}<1 \in\left\{1-\omega_{\text {in }}-\eta_{\text {Soe }}, \omega_{i n}, \eta_{\text {Soe }}\right\}$ the employment share of firms of type $\mathrm{k}$ in the domestic country $\left(\forall k \in\left\{d, f^{*}, S\right\}\right)$ :

$$
Y_{k, t}=\int_{0}^{s_{k}} \int_{0}^{n} Y_{k, t}(i) d i d j \quad K_{k, t}=\int_{0}^{s_{k}} \int_{0}^{n} K_{k, t}(i) d i d j \quad I_{k, t}=\int_{0}^{s_{k}} \int_{0}^{n} I_{k, t}(i) d i d j
$$

-with $s_{l}<1 \in\left\{1-\omega_{\text {out }}, \omega_{\text {out }}, \eta_{\text {Soe }_{f}}\right\}$ the employment share of firms of type 1 in the foreign country $\left(\forall l \in\left\{f, d^{*}, S_{f}\right\}\right):$

$$
Y_{l, t}=\int_{0}^{s_{l}} \int_{0}^{m} Y_{l, t}(u) d u d v \quad K_{l, t}=\int_{0}^{s_{l}} \int_{0}^{m} K_{l, t}(u) d u d v \quad I_{l, t}=\int_{0}^{s_{l}} \int_{0}^{m} I_{l, t}(u) d u d v
$$

Firms belong to households so profits are transferred to households' budget constraint. Thus, the Net Foreign Assets position is obtained consolidating households and firms' budget constraints:

$$
\begin{array}{r}
N F A_{d, t}=F B_{d, t}-F B_{f, t}=I_{f, t}^{*}-I_{d, t}^{*}+\alpha_{d} Y_{d, t}^{*}-\alpha_{f} Y_{f, t}^{*}+\left(1+r_{f, t}\right)\left(1-\gamma_{f}\right) F B_{d, t-1} \\
-\left(1+r_{d, t}\right)\left(1-\gamma_{d}\right) F B_{f, t-1}-\frac{\chi_{d}}{1+\mu_{d}}\left(F B_{d, t}-F B_{d, t-1}\right)^{1+\mu_{d}}+\frac{\chi_{f}}{1+\mu_{f}}\left(F B_{f, t}-F B_{f, t-1}^{*}\right)^{1+\mu_{f}}
\end{array}
$$

with:

$$
N F A_{d, t}+N F A_{f, t}=0
$$


The current account is defined as the sum of the trade balance and net incomes from abroad:

$$
\begin{array}{r}
C A_{d, t}=T B_{d, t}+N I C_{d, t}=Y_{d, t}+Y_{f, t}^{*}+Y_{S, t}-C_{d, t}-I_{d, t}-I_{f, t}^{*}+I_{S, t} \\
+r_{f, t}\left(1-\gamma_{f}\right) F B_{d, t-1}-r_{d, t}\left(1-\gamma_{d}\right) F B_{f, t-1} \\
+\frac{\chi_{f}}{1+\mu_{f}}\left(F B_{f, t}-F B_{f, t-1}\right)^{1+\mu_{f}}-\frac{\chi_{d}}{1+\mu_{d}}\left(F B_{d, t}-F B_{d, t-1}\right)^{1+\mu_{d}}
\end{array}
$$

\begin{tabular}{|c|c|c|c|}
\hline name & definition & name & definition \\
\hline & In the domestic country (China): & & In the foreign country (the rest of the world): \\
\hline$C_{d, t}$ & consumption & $C_{f, t}$ & consumption \\
\hline$N_{d, t}$ & labor supply in domestic private firms & $N_{f, t}$ & labor supply in foreign firms \\
\hline$N_{f, t}^{*}$ & labor supply in expatriate foreign private firms & $N_{d, t}^{*}$ & labor supply in expatriate Chinese private firms \\
\hline$N_{S, t}^{J, t}$ & labor supply in domestic SOEs & $N_{S_{f}, t}$ & labor supply in foreign SOEs \\
\hline$W_{d, t}$ & wages in domestic private firms & $W_{f, t}$ & wages in foreign firms \\
\hline$W_{f, t}^{*}$ & wages in expatriate foreign private firms & $W_{d, t}^{*}$ & wages in expatriate Chinese private firms \\
\hline$W_{S, t}^{j, t}$ & wages in domestic SOEs & $W_{S_{f}, t}^{u, t}$ & wages in foreign SOEs \\
\hline$B_{d, t}$ & bonds financing private firms in China & $B_{f, t}$ & bonds financing foreign private firms \\
\hline$B_{S, t}$ & bonds financing domestic SOEs & $B_{S_{f}, t}$ & bonds financing foreign SOEs \\
\hline$D_{d, T, t}$ & total deposit & $D_{f, T, t}$ & total deposit \\
\hline$F B_{d, t}$ & China's foreign bonds purchases & $F B_{f, t}$ & foreign bond purchases by the rest of the world \\
\hline$r_{d, t}$ & real interest rate & $r_{f, t}$ & real interest rate \\
\hline$\pi_{d, t}$ & profits of domestic private firms & $\pi_{f, t}$ & profits of foreign firms \\
\hline$\pi_{f, t}^{*}$ & profits of expatriate foreign private firms & $\pi_{d, t}^{*, t}$ & profits of expatriate Chinese private firms \\
\hline$\pi_{S, t}$ & profits of domestic SOEs & $\pi_{S_{f}, t}^{a,}$ & profits of foreign SOEs \\
\hline$\pi_{d, T, t}$ & total profits in the domestic country & $\pi_{f, T, t}$ & total profits in the foreign country \\
\hline$Y_{d, t}$ & production in domestic private firms & $Y_{f, t}$ & production in foreign firms \\
\hline$Y_{f, t}^{*}$ & production in expatriate foreign private firms & $Y_{d, t}^{*}$ & production in expatriate Chinese private firms \\
\hline$Y_{S, t}$ & production in domestic SOEs & $Y_{S_{f}, t}$ & production in foreign SOEs \\
\hline$K_{d, t}$ & capital in domestic private firms & $K_{f, t}$ & capital in foreign firms \\
\hline$K_{f, t}^{*}$ & capital in expatriate foreign private firms & $K_{d, t}^{*}$ & capital in expatriate Chinese private firms \\
\hline$K_{S, t}$ & capital in domestic SOEs & $K_{S_{f}, t}$ & capital in foreign SOEs \\
\hline$I_{d, t}$ & investment by domestic private firms & $I_{f, t}$ & investment by foreign firms \\
\hline$I_{f, t}^{*}$ & investment by expatriate foreign private firms & $I_{d, t}^{*}$ & investment by expatriate Chinese private firms \\
\hline$I_{S, t}$ & investment by domestic SOEs & $\begin{array}{l}a, t \\
I_{S_{f}, t}\end{array}$ & investment by foreign SOEs \\
\hline$G_{d, t}$ & public expenditures & $G_{f, t}$ & public expenditures \\
\hline$N F A_{d, t}$ & net foreign assets & $N F A_{f, t}$ & net foreign assets \\
\hline$C A_{d, t}$ & current account & $C A_{f, t}$ & current account \\
\hline
\end{tabular}

It can also be expressed as a function of savings and investments: $C A_{d, t}=S_{d, T, t}-I_{d, T, t}$.

Note: parameters are described in Table 2 in the calibration subsection.

Table 1: Variables 


\subsection{Calibration}

The model is annual. The calibration is based on data from 2014 to 2017 (according to availability), on the literature on China using DSGE models, and the calibration targets some main variables' steady states. Indeed, the first crucial issue is to reach the following: a low consumption rate (approximately $42 \%$ of GDP), a high investment rate (approximately $40 \%$ of $\mathrm{GDP}^{14}$ ), a high NFA position (approximately $31 \%$ of GDP, including recent higher foreign liabilities (14\% of GDP)), a trade balance surplus (close to $5 \%$ of GDP), and a $3 \%$ real deposit rate. Moreover, even if it is not the main purpose, we attempt to obtain realistic values for FDI flows (less than $5 \%$ of GDP).

Another crucial element is to have quite accurate values of the initial level of technology (compared to the rest of the world) and of TFP growth across each type of firm. Indeed, the Chinese transition was based on the huge TFP growth over the last 30 years $\left(g_{A_{d}}>g_{A_{f}}\right.$ to have a larger TFP growth in China than in the rest of the world), but there is still a large gap with the most developed countries regarding the level of technology $\left(A_{f, 0}=1\right.$ and $A_{d, 0}=0.53$, according to St Louis Fed Stats and author's calculations). Moreover, the recent catch-up process of TFP growth by SOEs versus private firms may be taken into account (Hsieh and Song, 2015). Thus, private firms have a higher initial TFP level than $\operatorname{SOEs}\left(A_{d, 0}=0.53 ; A_{S, 0}=0.5\right)$, but TFP has a higher growth rate in SOEs $\left(g_{A_{S}}=0.33 ; g_{A_{d}}=0.3\right)$. $A_{0}$ of expatriate firms is from the home country, which means that foreign firms in China have a higher initial technology level than domestic firms $\left(A_{f, 0}>A_{d, 0}\right)$ but have the same local TFP growth. Note that some authors attempt to account for China's TFP growth across sectors and ownership but the variance is high across studies; here, the calibration is particularly based on Brandt and Zhu (2010) and Hsieh and Song (2015) $\left(g_{A_{d}}=0.3\right.$ and $\left.g_{A_{S}}=0.33\right)$.

Credit constraints are slightly higher in China $\left(\zeta_{d}=0.385\right)$ than in financially integrated countries for example $\left(\zeta_{f}=0.42\right)$ but are heavily relaxed for SOEs $\left(\zeta_{S}=0.57\right) .{ }^{15}$ Their calibration, coupled to the capital shares' calibrations ( 0.285 in private firms; 0.45 in SOEs), attempts to match the highest investment rate in China possible in this model (44\% in the 2015-2017 data). The calibration of the other parameters (capital depreciation (0.08), adjustment costs (0.2), inverse of Frisch elasticity (0.43), etc.) remains close to the literature, while setting the main variables' steady states close to the data. The share of SOEs in China $\left(\eta_{S o e}=0.47\right)$ and the share of China's GDP $\left(\varrho_{Y}=0.15\right)$ are initially fixed, and then evolve endogenously. ${ }^{16}$ The calibration and its justification are summarized in Table 2.

The initial calibration of taxes (Table 2) is based on data from China Statistical Yearbook, author's calculations (mainly for the mean of all sectors), the State Administration of Taxation of the People's Republic of China, social insurance law (in "China Labour Bulletin") and the Deloitte report "China Taxation and Investment 2016". Note that there is a lack of data concerning the social contributions by type of ownership (at a national level). Thus, for this tax in particular the values are initially the same for all ownerships (at the initial steady state, and then they have heterogeneous values along the reforms). Regarding the tax $\gamma$, it is a new tax that is not currently applied in China, thus we consider a value for all firms that matches a $3 \%$ steady state real deposit rate (annual basis).

\footnotetext{
${ }^{14}$ In this model, it is very difficult to obtain the $44 \%$ investment rate in the 2015 -2017 data. Therefore, the aggregated investment rate does not exceed $38 \%$ of GDP.

${ }^{15}$ Firms can borrow a share $\zeta$ of their capital stock $\left(B_{t}=\zeta K_{t}\right)$, see Equations 14 and 15 .

${ }^{16}$ Note that the initial share of SOEs is assigned to the hours worked, and the initial share of GDP to all household variables (which then impact all variables): $\left[\frac{N_{d, t}}{\left(1-\eta_{S o e}\right) \varrho_{Y}}\right]^{\psi}\left[\frac{C_{d, t}}{\varrho_{Y}}\right]^{\sigma}=w_{d, t}\left(1+\tau_{w_{d}}\right.$ ) (in domestic private firms in China, for example). Thus, these parameters adjust the labor supply but can not force the labor supply to have a precise specific value. With $\eta_{\text {Soe }}=0.47$, the share of employment in SOEs at steady state is $53 \%$, which remains very close to the data (China Statistical Yearbook).
} 


\begin{tabular}{ll}
\hline \hline Parameters & China \\
\hline
\end{tabular}

\section{Households}

$\sigma$

$\psi$

$\mu$

$\chi$

Firms

$A_{0}$

$g A$

$\alpha$

$\delta$

$\Phi_{I}$

$\zeta$ discount rate

risk aversion

inverse of Frisch elasticity

curvature of bonds' trading costs

bonds trading costs

initial technology

TFP growth

share of capital in production

capital depreciation rate

investment adjustment costs

access to credit

initial share of SOEs

initial share of GDP

$\begin{array}{cc}\text { private firms } & 0.53 \\ \text { SOEs } & 0.5 \\ & \\ \text { private firms } & 0.03 \\ \text { SOEs } & 0.033 \\ \text { private firms } & 0.285 \\ \text { SOEs } & 0.45 \\ & \\ & 0.08 \\ & 0.2 \\ \text { private firms } & 0.385 \\ \text { SOEs } & 0.57\end{array}$

$\eta_{S^{2}}{ }^{2}$

\section{Government}

$\begin{array}{ll}\tau_{w_{d}} \quad & \text { tax on labor cost } \\ & \text { (social security contribution) })^{3} \\ & \text { in private domestic firms }\end{array}$

$\begin{array}{ll}\tau_{w_{f} *} & \text { tax on labor cost } \\ & \text { (social security contribution) })^{3} \\ & \text { in private foreign firms } \\ \tau_{w_{s}} & \text { tax on labor cost } \\ & \text { (social security contribution) }{ }^{3} \\ & \text { in SOEs } \\ & \text { financial transaction tax } \\ \gamma_{d} & \text { for private domestic firms } \\ & \text { financial transaction tax } \\ \gamma_{f^{*}} & \text { for private foreign firms } \\ & \text { financial transaction tax } \\ \gamma_{S} & \text { for SOEs } \\ & \text { tax on production } \\ \tau_{y_{d}} & \text { (business or sales tax) } \\ & \text { in private domestic firms } \\ & \text { tax on production } \\ \tau_{y_{f} *} & \text { (business or sales tax) } \\ & \text { in private foreign firms } \\ & \text { tax on production } \\ & \text { (business or sales tax) } \\ \tau_{y_{s}} & \text { in SOEs }\end{array}$

in SOEs
0.97

1

0.43

0.85

to match a $3 \%$ steady-state real deposit rate (annual basis) constrained by the balanced growth path ${ }^{1}$ Reichling and Whalen (2012) and to reach a low consumption-to-output ratio to have quadratic costs

$$
(1+\mu)
$$$$
\text { to reach a high NFA }
$$$$
\text { position }
$$

St Louis Fed Stats,

Hsieh and Song (2015),

and author's calculations

Brandt and Zhu (2010)

and Hsieh and Song (2015)

Bénassy-Quéré et al. (2013),

Funke et al. (2015), and to

reach a high investment rate

Bénassy-Quéré et al. (2013)

Albonico et al. (2012)

close to Coeurdacier et al. (2015),

to match differences between private firms and SOEs (Poncet et al., 2010;

Song et al., 2011, ...), to reach high investment rates in China, and to target other steady-state values

China Statistical Yearbook (CSY) World Bank

State Administration of Taxation of the People's Republic of China, social insurance law ("China Labour Bulletin") and "China Taxation and Investment 2016" (Deloitte) ",

$" n$

to match a $3 \%$ steady state real deposit rate $"$ "

0

0

$", "$

0

0.0059

China Statistical Yearbook (CSY) and author's calculations ${ }^{4}$

0.0064

$" n$

0.0395

${ }^{1}$ It is well known that with separable preferences, because the model is solved along the balanced growth path, labor supply equations force the risk aversion parameter to be equal to 1.2 The initial share of SOEs is assigned to the hours worked, and the initial share of GDP to all household variables, which then impact all variables; for example, in domestic private firms in China we have: $\left[\frac{N_{d, t}}{\left(1-\eta_{S o e}\right) \varrho_{Y}}\right]^{\psi}\left[\frac{C_{d, t}}{\varrho_{Y}}\right]^{\sigma}=$ $W_{d, t}\left(1+\tau_{w_{d}}\right)$.

${ }^{3}$ It is the sum of all social security contributions levied on labor cost (pension, unemployment and medical insurance). Note that there is a lack of data concerning the social contributions by type of ownership (at a national level).

${ }^{4}$ According to CSY, taxes on firms' production (business taxes) vary by sectors (manufacturing and tertiary); thus it is the weighted mean of all available sectors.

Table 2: Calibration of the benchmark model 


\subsection{Taxes' impact on steady state}

\begin{tabular}{|c|c|c|c|c|}
\hline \multirow[b]{2}{*}{$\begin{array}{l}\left(\bar{x}_{y} \text { are variables in } \% \text { of GDP at steady state; }\right. \\
\bar{n} \text { is a fraction of time; } \bar{w} \text { is a wage index })\end{array}$} & \multirow{2}{*}{$\begin{array}{l}\text { Steady state } \\
\text { All taxes }\end{array}$} & & \multicolumn{2}{|c|}{$\begin{array}{l}\text { Variation of } \\
\text { steady state (\%) }\end{array}$} \\
\hline & & & $\begin{array}{c}\tau_{y_{d, f^{*}, S}} \\
\text { loosened }\end{array}$ & $\begin{array}{l}\tau_{w_{d, f} *, S} \\
\text { loosened }\end{array}$ \\
\hline $\begin{array}{l}\bar{y} \\
\left(\bar{y}_{d}=0.086, \bar{y}_{f^{*}}=0.066, \bar{y}_{S}=0.167\right)\end{array}$ & 0.32 & $\frac{\Delta \bar{y}}{\bar{y}}$ & 16.24 & 0.53 \\
\hline $\bar{s}_{y}$ & 49.41 & $\frac{\Delta \overline{s_{y}}}{\overline{s_{y}}}$ & -12.27 & 0.40 \\
\hline $\bar{g}_{y}$ & 16.01 & $\frac{\Delta \frac{g}{g_{y}}}{g_{y}}$ & -13.40 & -85.78 \\
\hline$\overline{t b}_{y}$ & 5.5 & $\frac{\frac{\Delta g}{t b_{y}}}{t \overline{t b_{y}}}$ & 118.97 & 23.91 \\
\hline$\overline{n f a}_{y}$ & 30.89 & $\frac{\Delta \frac{\Delta y a_{y}}{n f a_{y}}}{\overline{n+1}}$ & -21.52 & -0.65 \\
\hline$\overline{W e l f}$ & -71.13 & $\frac{\Delta \bar{W}}{\bar{W}}$ & -1.72 & 11.98 \\
\hline Households & & & & \\
\hline $\bar{c}_{y}$ & 41.96 & $\frac{\Delta \overline{c_{y}}}{\overline{c_{y}}}$ & -14.94 & 29.62 \\
\hline $\begin{array}{l}\bar{n} \\
\left(\bar{n}_{d}=38.79 \% \text { total, } \bar{n}_{f^{*}}=11.79 \% \text { total }\right. \\
\left.\bar{n}_{S}=49.41 \% \text { total }\right)\end{array}$ & 0.37 & $\frac{\Delta \bar{n}}{\bar{n}}$ & 14.99 & 0.72 \\
\hline $\begin{array}{l}\left.\bar{w}^{\left(\bar{w}_{d}\right.}=0.33, \bar{w}_{f^{*}}=0.83, \bar{w}_{S}=0.37\right)\end{array}$ & 0.43 & $\frac{\Delta \bar{w}}{\bar{w}}$ & 7.76 & 35.87 \\
\hline Firms & & & & \\
\hline $\begin{array}{l}\bar{i}_{y} \\
\left(\bar{i}_{d}=26.58, \bar{i}_{f^{*}}=27.69, \bar{i}_{S}=45.14\right)\end{array}$ & 37.1 & $\frac{\Delta \overline{i_{y}}}{\overline{i_{y}}}$ & 3.51 & 1.56 \\
\hline$\overline{f d i}_{i n, y}$ & 5.75 & $\frac{\Delta \overline{f d i}_{i n_{y}}}{\overline{f d i}_{i n_{y}}}$ & 0.08 & $\approx 0\left(-0.44\right.$ for $\left.\frac{\Delta \overline{f d i}_{i n}}{\overline{f d i}_{i n}}\right)$ \\
\hline$\overline{f d i}_{\text {out }, y}$ & 3.66 & $\frac{\Delta \overline{f d i} \text { out }_{y}}{\overline{f d i_{\text {out }}}}$ & -20.16 & 20.36 \\
\hline $\bar{\Pi}$ & 0.0157 & $\frac{\Delta \overline{\bar{\Pi}}^{9}}{\overline{\bar{\Pi}}}$ & 24.7 & 1.7 \\
\hline $\bar{\Pi}_{y}$ & 4.92 & $\frac{\Delta \bar{\Pi}_{y}}{\bar{\Pi}_{y}}$ & 3.73 & 0.8 \\
\hline
\end{tabular}

Table 3: Taxes' contribution to steady steate

In this subsection, we are interested in the changes in variables' steady state (including public expenditure) when a specific tax is loosened while the other taxes remain constant.

When $\tau_{y}$ (business taxes levied on firms' production in China) is loosened (until 0\%), firms' output, profits and investment rate increase (because sales are no more reduced by $\tau_{y}$ ), and public spending mechanically decreases (Table 3). The changes in firms' output also lead to an increase in labor demand and wages. Note that the effect on inward FDI is negligible whereas outward FDI are widely impacted. Indeed, with this calibration, taxes on production can be lower in the foreign country for some firms: outward FDI are a way to escape the local taxation at the rate $\tau_{y}$ in the domestic country; thus, when the latter is loosened, capital is repatriated. On the household side, the rise in firms' indebtedness (due to the rise in output and investment) mechanically increases the amount of domestic bonds that are purchased by households in this model. The consequence is a negative effect on consumption. Concerning the trade balance, its 
high sensitivity is due to the sum of all of the changes in output, investment, consumption and public spending. ${ }^{17}$ The main effects are the rise of firms' competitiveness when business taxes are removed (increasing exports) and the negative variation of consumption described above (decreasing imports). When $\tau_{w}$ (levied on wages in China) is loosened (from 29 to $0 \%$ ), there is a direct and drastic negative effect on public spending (Table 3) because social security contributions represented the main part of the tax collection. Consumption and welfare are positively and highly impacted because household income mechanically increases when social security contributions are removed.

Concerning the loosening of $\gamma$, the changes in steady state are not reported in Table 3. Indeed, it only has an effect on the dynamics of corporate debts and not on changes in other variables' steady states. The real interest rate falls quite substantially over time to adjust to the change in $\gamma$.

\section{Tax reforms}

The first reform is to decrease the overinvestment rate of some Chinese firms (Ding et al., 2016). Indeed, the latter has been between $44 \%$ and $48 \%$ of GDP in the data ${ }^{18}$ these last eight years (Figure 1) and has led to huge indebtedness, default or overcapacities (Aglietta and Landry, 2007; Zhou, 2013; Borst and Lardy, 2015; IMF, 2015; Artus, 2016a).

Second, the recent main goal of Chinese government policy is to raise domestic consumption and reduce the dependence on foreign demand. By implementing various taxes, the model is computed to target a second steady state with a higher consumption-output ratio (which has been below $40 \%$ in the data between 2012 and $2017^{18}$, see Figure 2). The response function of other key variables (trade balance, net foreign assets position, FDI, investment rate, etc.) is also analyzed.

Note that with a lower investment rate (targeted by the first tax reform), the government can also stimulate consumption in this model. Indeed, the decrease in firms' investment is obtained by higher credit costs for firms and by a reallocation of the labor force. The former increases returns on household savings and the latter raises the share of employment in firms with higher wages. These two elements increase the share of consumption in GDP during the reforms that reduce overinvestment.

Then, one main goal of Chinese government policy is to increase social welfare. For this reason, the welfare benefits of the policy reforms are computed and analyzed. Here, welfare benefits are represented by the percentage of consumption $\xi$ that would offset households' welfare losses between the reform and the initial steady state, as in Auray et al. (2016). It is the value of $\xi$, which solves the following:

$$
\sum_{t=0}^{i} \beta^{t} U\left(C_{d, t}(1-\xi), N_{d, t}, N_{f^{*}, t}, N_{S, t}\right)=U\left(\bar{C}_{d}, \bar{N}_{d}, \bar{N}_{f^{*}}, \bar{N}_{S}\right) \sum_{t=0}^{i} \beta^{t}, i=1 \ldots \infty
$$

When $\xi$ is negative (resp. positive) the reform brings welfare losses (resp. gains): households must be compensated during the reform to maintain the same level of welfare. The welfare benefits are observed either at short horizons (2 to 10 years) or at 20 years and infinite horizon (across steady states); they are computed during the consumption and investment reforms. The welfare reaction to stochastic shocks to TFP is also tested. Finally, the Appendix develops an extension of the model that includes prices of goods and heterogeneous Value Added Taxes (VATs) across home and foreign goods (during the reforms that increase the consumption ratio).

\footnotetext{
${ }^{17}$ In this framework, the trade balance is obtained with the aggregation of domestic and foreign clearing conditions on the goods and services markets (Equation 29).

${ }^{18}$ Source: World Bank database.
} 


\subsection{Reduce overinvestment}

The first reform is to reach a lower aggregate investment rate, and thus reduce overinvestment in firms that have lower credit constraints. To establish the reform, we seek the transition path of all variables $\left\{X_{1, t}, X_{2, t}, \ldots, X_{n, t}\right\}_{t=0}^{T}$ that solves:

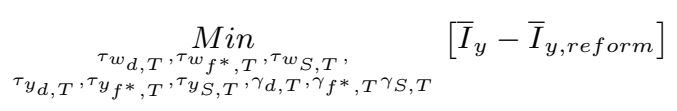

with $\bar{I}_{y}<0.37$ and subject to steady state equations, market clearing conditions and aggregation. Each tax follows a first-order autoregressive process during the reform: $\tau_{t}=\rho_{\tau} \tau_{t-1}+\left(1-\rho_{\tau}\right) \bar{\tau}$, where $\bar{\tau}$ is the tax value at the final steady state of the reform.

The model is computed with a target of the investment rate below the initial steady state. We recall that the investment rate varies a lot between the different types of firms in the model $(46 \%$ for SOEs versus $26 \%$ and $27 \%$ for private domestic and foreign firms, respectively) and that SOEs represent approximately half of the labor supply in China (10\% and $40 \%$ for foreign and domestic private firms, respectively). We ensure that the solution is unique by running again the algorithm and excluding the first solution (if the solution is unique, the algorithm does not find any solution after the second set of iterations).

According to Table 4, taxes on SOE bonds are lower (0.0108, against 0.03 before tax reforms), increasing credit cost of SOEs during the transition path $\left(\Delta_{-} \gamma_{S, t} \Rightarrow \Delta_{+} r_{d, t}\left(1-\gamma_{S}\right)\right)$. Thus, it leads to a drop in SOEs' investment rate (to $39 \%$, against $46 \%$ initially, Figure 6 , panel (a)), whereas the latter remains broadly constant in private domestic and foreign firms (panels (b) and (c)). Regarding the business tax, it increases more in SOEs (0.0477) than in private domestic and foreign firms $(0.0075$ and 0.007 , respectively). The result is consistent with firms' characteristics because SOEs benefit from relaxed credit constraints, high TFP growth, and low wages (thus, they have the highest investment rate $(46 \%))$. Moreover, wages in SOEs are taxed more heavily (Table 4), which is equivalent to increase social security contributions of SOEs and to reduce/maintain social security contributions of private domestic and foreign firms.Thus, the labor supply in SOEs is largely reduced (Figure 6, panel (d)): through the increase in social security contributions and business tax in SOEs, there is a progressive reallocation of the labor force toward firms that faced higher credit contraints before the reforms (in addition to hindering investment in SOEs). It is currently the case in China: the government shuts down some state-owned factories because of overcapacities due to overinvestment, and then reallocates the labor force. ${ }^{19}$

As expected, a low investment rate target leads to a higher consumption-to-GDP ratio (Figure 5, panel (g)). First, firms' deleveraging reduces the household holdings of domestic bonds, which decreases the share of savings directed to bonds with low returns. Then, the reallocation of the labor force to firms with higher wages, through higher social security contributions in SOEs, further raises the consumption ratio. Moreover, these tax reforms also slow the increase in foreign firms' wages, whereas wages increase slightly faster in domestic private firms. Thus, there is a slight adjustment in the increase in labor costs between domestic and foreign firms, which strengthens the rise in consumption.

\footnotetext{
${ }^{19}$ It is particularly the case in the steel sector since 2016, in which low prices are a means to sell the ouput but the latter create tensions with the European Union.
} 
Welfare benefits are observed under the reforms that lower the investment rate (Table 4) but they are substantially smaller than under the reforms that increase the consumption ratio (Table 5). One explanation is a smaller decrease in hours spent at work: the labor force is largely reallocated, contrary to the reform that increases consumption (during which aggregate hours spent at work widely decrease). Moreover, the reaction of welfare after stochastic shocks to TFP is dampened after tax reforms (Table 4); it is due to new taxes that favor the adjustment of consumption to maintain the level of welfare. In the following reform that increases consumption (next subsection), we even observe a significant reduction of welfare volatility after the same shock (Table 5).

Concerning external positions, even if the investment rate falls, the large increase in consumption creates a trade balance deficit (Figure 5, panel (i)). Moreover, the large and positive Net Foreign Asset position cannot be corrected despite the domestic reform (panel (h)), as in Fukumoto and Muto (2011). Indeed, firms' profits and the household propensity to save remain large, and then the domestic investment rate decreases, which lowers the supply of domestic bonds. Thus, a higher share of aggregate savings finances foreign investments (this mechanism is also highlighted as a current fact in Artus, 2016b). Regarding FDI, the positive effect of the financial transactions tax (reducing bond refunding for private firms) overturns the slight negative effect of the taxation of production. Thus, foreign firms are even more attracted by a relocation to China (Figure 5, panel $(\mathrm{k})$ ). ${ }^{20}$ However, the outward FDI-to-GDP ratio decreases during the transition because of the difference in the balanced growth path between output and investment (panel (l) $).^{21}$

For these reforms, most of the taxes that concern the larger share of firms (SOEs) increase or remain quite stable. Therefore, we can observe an increase in tax collection and thus in government spending (Figure 5, panel (n)). The rise in social contributions also impacts the labor utilization of SOEs, however, there is a reallocation of the labor force to the other firms. Thus, overall, the reforms that are examined just slightly reduce the activity: in the long run, the GDP growth is reduced by less than 0.5 percentage point for the tax reforms reducing overinvestment, and by approximately 0.1 percentage point for the tax reforms increasing consumption (Figure 5, panel (m)).

\begin{tabular}{|c|c|c|c|c|c|c|}
\hline Taxes & Initial & Reform & Horizon & Welfare benefits $(\xi)$ & & Welfare volatility \\
\hline$\tau_{y_{d}}$ & 0.0059 & 0.0075 & 2 & 0.0095 & & (after a stochastic \\
\hline$\tau_{y_{f} *}$ & 0.0064 & 0.007 & 5 & 0.0167 & & TFP shock (\%)) \\
\hline$\tau_{y_{S}}$ & 0.0395 & 0.0477 & 10 & 0.0181 & Before reforms & 12.84 \\
\hline$\gamma_{d}$ & 0.03 & 0.0339 & 20 & 0.0121 & After reforms & 12.21 \\
\hline$\gamma_{f} *$ & 0.03 & 0.0334 & across & 0.0126 & & \\
\hline$\gamma_{S}$ & 0.03 & 0.0108 & steady states & & & \\
\hline$\tau_{w_{d}}$ & 0.29 & 0.2696 & & & & \\
\hline$\tau_{w_{f}}$ & 0.29 & 0.2964 & & & & \\
\hline$\tau_{w_{S}}$ & 0.29 & 0.3494 & & & & \\
\hline
\end{tabular}

Table 4: Taxes and welfare benefits - Reform 1: investment

\footnotetext{
${ }^{20}$ In the model and in reality, intward FDI can benefit from local funding in China (Du and Girma, 2007).

${ }^{21}$ Outward FDI benefit from the TFP growth of the rest of the world, whereas China's TFP growth, which is higher, is accounted for in GDP.
} 


\subsection{Increase the consumption ratio}

To establish the reform that increases the consumption share in GDP, we seek the transition path of all variables $\left\{X_{1, t}, X_{2, t}, \ldots, X_{n, t}\right\}_{t=0}^{T}$ that solves:

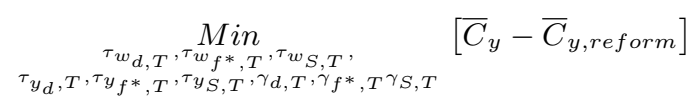

with $\bar{C}_{y}=0.5^{22}$ and subject to steady state equations, market clearing conditions and aggregation. Each tax follows a first-order autoregressive process during the reform: $\tau_{t}=\rho_{\tau} \tau_{t-1}+\left(1-\rho_{\tau}\right) \bar{\tau}$, where $\bar{\tau}$ is the tax value at the final steady state of the reform. Similar to the reforms that target a low investment rate, we ensure that the solution is unique by running again the algorithm and excluding the first solution. ${ }^{23}$

In the final steady-state, the tax on bond refunding is higher in private firms $\left(\gamma_{d}\right)$ than in SOEs $\left(\gamma_{S}\right.$, Table 5). The implication is that bond refunding in private firms (resp. SOEs) decreases (resp. increases) during the transition $((1+\mathrm{r})(1-\gamma))$, which offsets the higher credit constraints in private firms compared to SOEs. Thus, returns on households' SOE bonds (resp. private firm bonds) increase (resp. decrease), and the increase in returns on SOE bonds is higher than the decrease in private firm bonds returns $\left(\Delta_{-} \gamma_{S, t}>\Delta_{+} \gamma_{d, t} \Rightarrow \Delta_{+} r_{d, t}\left(1-\gamma_{S}\right)>\Delta_{-} r_{d, t}\left(1-\gamma_{d}\right)\right)$. Therefore, the aggregate returns on households' bonds increase, which enhances their consumption through a wealth effect. We can also observe that social security contributions in foreign firms strongly decrease during this reform. Given that wages are to a large extent higher in foreign firms in the initial steady state, computation simply reduces taxation on the highest wage index to reach the consumption target. A consequence is the rise in the labor supply in foreign firms and a reduction in SOE labor supply (there is a minor reallocation of the labor force where wages and taxation allow for higher consumption and welfare).

Then, financial external surpluses are not corrected: similar to the reforms that target a low investment rate, the NFA position remains positive and can even increase (Figure 5, panel(h)). Indeed, with the rise in loan repayments for SOEs and in the taxation of production, the aggregate investment rate decreases. Thus, domestic savings (which are still high) are even more reallocated to foreign bonds.

The higher consumption level mechanically increases welfare benefits (Table 5) with the utility function $\frac{C_{d, t}^{1-\sigma}}{1-\sigma}-\frac{N_{S, t}^{1+\psi}+N_{d, t}^{1+\psi}+N_{f, t}^{* 1+\psi}}{1+\psi}$. Indeed, consumption is higher whereas time spent at work decreases because the taxation slows production and investment (Figure 5). The positive impact of the decrease in aggregate labor supply on welfare is high with this calibration because the scale factor in the utility function is equal to one.

Concerning other variables, this reform, which leads to a high domestic demand, clearly decreases the trade balance (a trade deficit progressively appears during the reform (Figure 5, panel (i)), and the real exchange rate is higher at the end of the reform (it corresponds to the situation with a higher purchasing power of households). As for FDI, firms' expatriation from China to the rest of the world rises at the beginning of the transition, but then, similar to the investment reform, the outward FDI-to-GDP ratio decreases during the transition path (panel (l)). The reason is the difference in balanced growth path between output and foreign investment. ${ }^{21}$ The positive change in inward FDI (panel $\left.(\mathrm{k})\right)$ is due to the reduction in credit distortions in China (expatriate firms can benefit from better local funding) and the

\footnotetext{
$2250 \%$ of GDP is the mean of the consumption ratio for upper middle income countries these last years (Source: World Bank database).

${ }^{23}$ Thus, if the solution is unique, the algorithm does not find any solution after the second set of iterations.
} 
rise in domestic consumption, which compensate for the higher taxation of firms' production. We also observe a significant reduction of welfare volatility after stochastic shocks to TFP (Table 5) because the new taxes favor the adjustment of consumption to maintain the level of welfare.

\begin{tabular}{|c|c|c|c|c|c|c|}
\hline Taxes & Initial & Reform & Horizon & Welfare benefits $(\xi)$ & & Welfare volatility \\
\hline$\tau_{y_{d}}$ & 0.0059 & 0.0068 & 2 & 0.0421 & & (after a stochastic \\
\hline$\tau_{y_{f}}$ & 0.0064 & 0.0072 & 5 & 0.0697 & & TFP shock (\%)) \\
\hline$\tau_{y_{S}}$ & 0.0395 & 0.0498 & 10 & 0.0732 & Before reforms & 12.84 \\
\hline$\gamma_{d}$ & 0.03 & 0.0335 & 20 & 0.0739 & After reforms & 10.97 \\
\hline$\gamma_{f^{*}}$ & 0.03 & 0.0328 & across & 0.0726 & & \\
\hline$\gamma_{S}$ & 0.03 & 0.0209 & steady states & & & \\
\hline$\tau_{w_{d}}$ & 0.29 & 0.2923 & & & & \\
\hline$\tau_{w_{f *}}$ & 0.29 & 0.2066 & & & & \\
\hline$\tau_{w_{S}}$ & 0.29 & 0.3311 & & & & \\
\hline
\end{tabular}

Table 5: Taxes and welfare benefits - Reform 2: consumption 


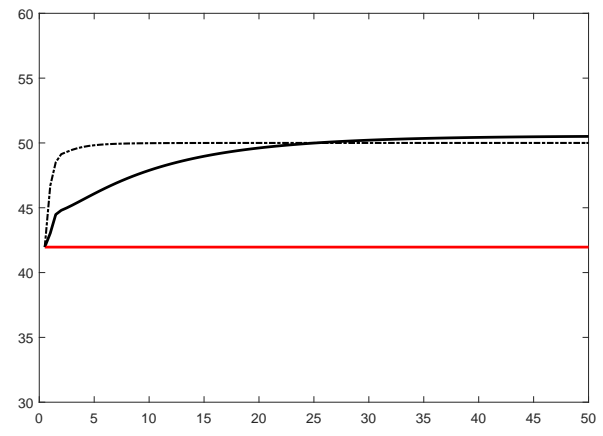

Trade balance (i)

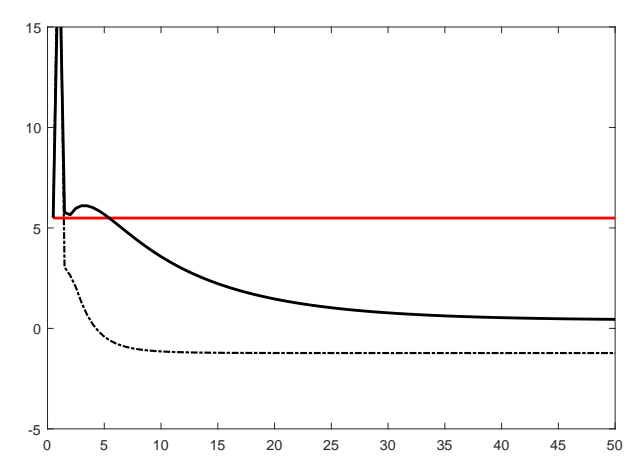

FDI inflows (k)

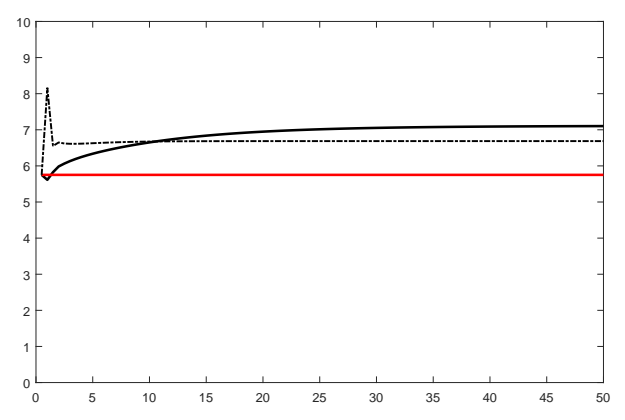

Gap in GDP growth

(before-after reforms, in percentage point) (m)

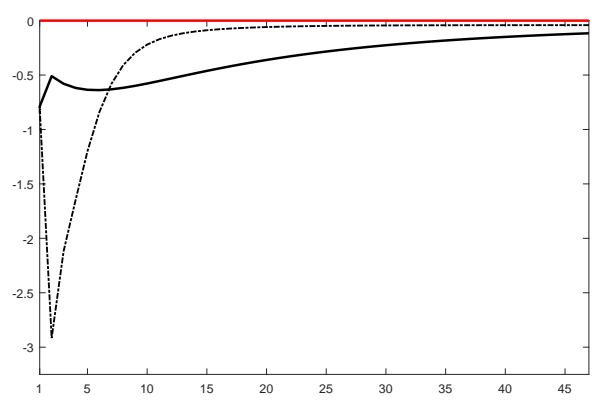

Legend

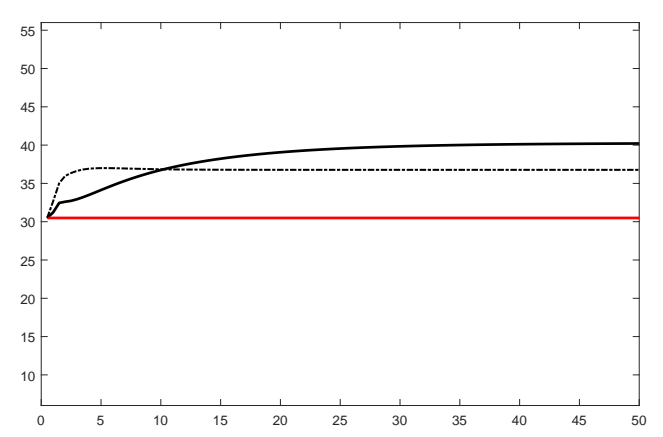

Aggregate investment rate $(\mathrm{j})$

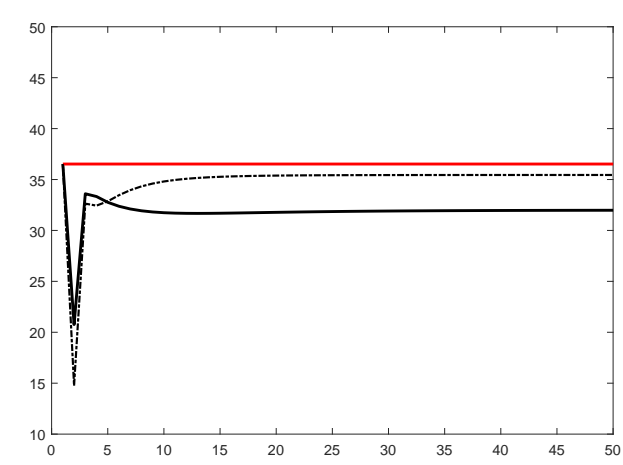

FDI outflows (1)

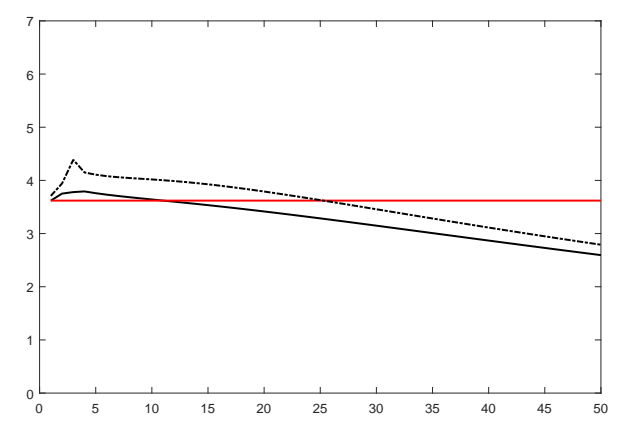

Government spending (n)

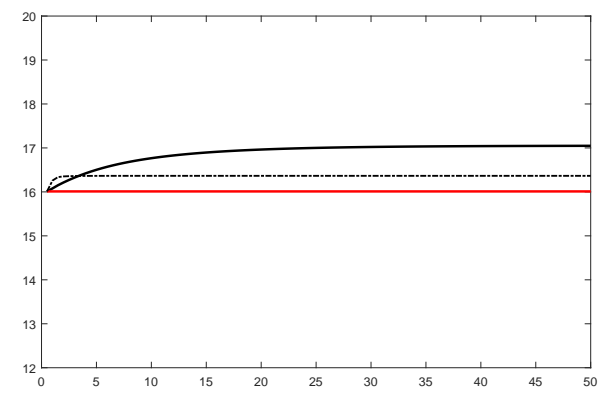

- Investment target (<37\% GDP)

- Initial steady state

---. Consumption target (>50\% GDP)

Figure 5: Main variables transition (\% GDP) - Investment and consumption reforms 
Investment rate - SOEs (a)

(\% GDP of SOEs)

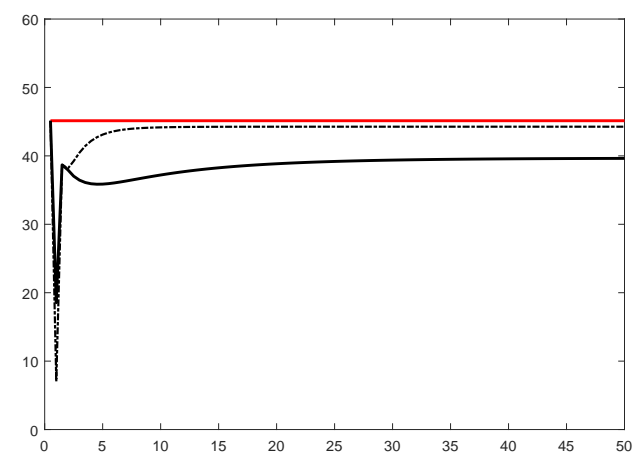

Investment rate - foreign firms (c) (\% GDP of foreign firms)

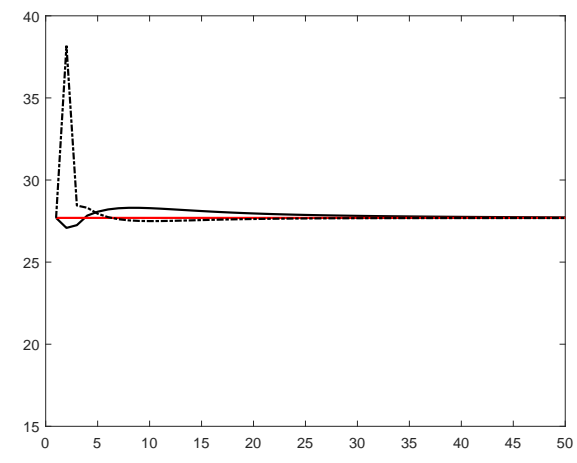

Labor supply - foreign firms (e) (\% total)

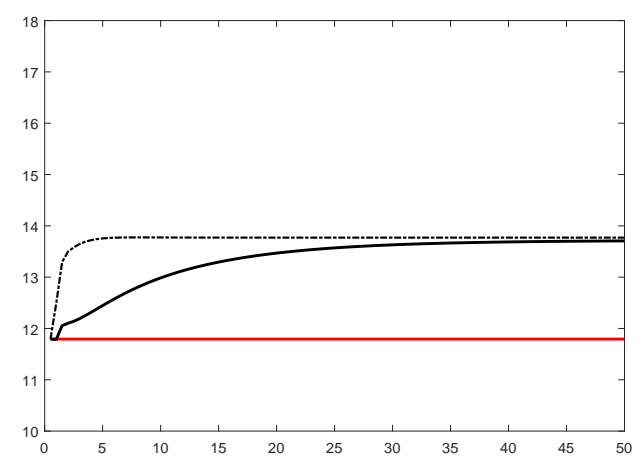

Legend
Investment rate - domestic private firms (b) (\% GDP of domestic private firms)

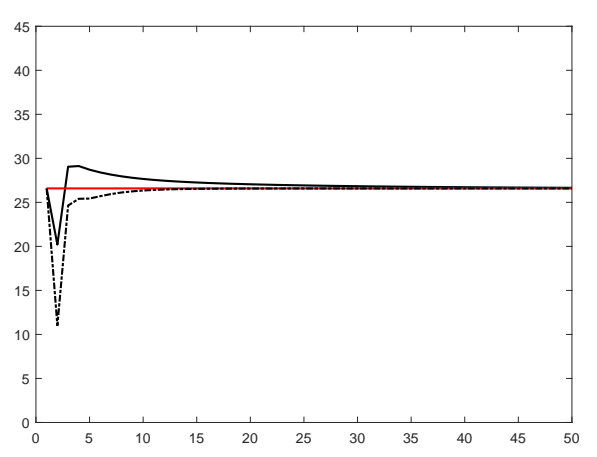

Labor supply - SOEs (d) (\% total)

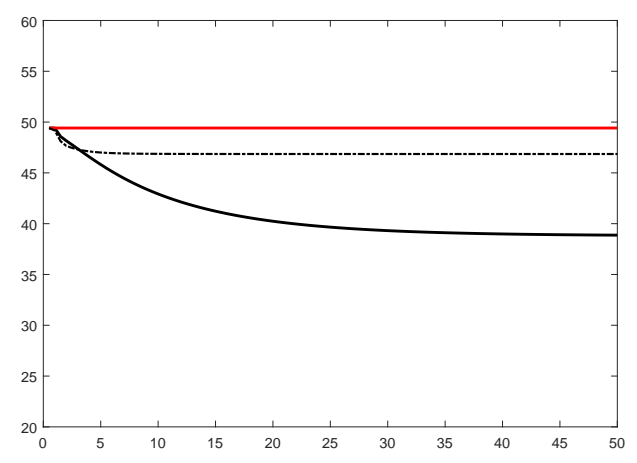

Labor supply - domestic private firms (f) (\% total)

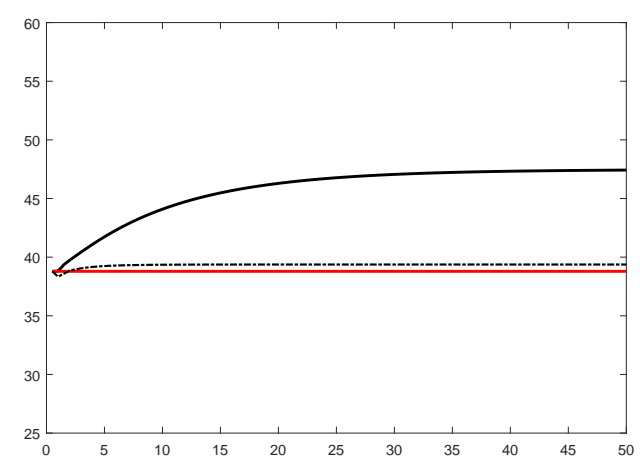

- Investment target (<37\% GDP)

_ Initial steady state

---- Consumption target (>50\% GDP)

Figure 6: Investment rates and labor supplies 


\section{Conclusion}

This paper identifies policy reforms in China that may enhance consumption, reduce some firms' overinvestment and increase the level of welfare, by taxing firms differently according to their production, access to credit and labor costs. Several results emerge from the dynamic general equilibrium model analysis.

First, for some reforms, it is necessary to correct the distortions in factor costs (capital and labor) that lead to domestic imbalances; that is, to increase loan repayments (via financial transactions taxes) for firms that face soft budget constraints and to reduce the wage differential between domestic and foreign firms (via social security contributions). Firms' credit cost is a key channel: it reacts to financial transactions taxes and impacts both firms' investment and household consumption (through returns on savings). Second, a reallocation of the labor force (via business taxes and social security contributions) from firms with soft budget constraints (SOEs) to firms with hard budget constraints (private firms) can significantly lower the investment rate (which was mainly due to SOEs) and thus overcapacities. This reallocation of the labor force to reduce overcapacities is currently in progress in China, but it is a critical issue because it creates significant shifts in migrations and in unemployment rates in some sectors (IMF, 2015). Thus, the restructuration of SOEs becomes a major challenge (IMF, 2015; Artus, 2016a; Leutert, 2016) that will allow reducing the magnitude of this labor force reallocation.

Third, reforms that enhance consumption or reduce the investment rate both raise welfare benefits for households and stabilize the welfare reaction to TFP shocks.

Finally, the particularity of the reforms in this framework is that domestic rebalancing does not necessarily require an external rebalancing of the financial position (as in Fukumoto and Muto, 2011). Indeed, the aggregate savings rate remains high, and the supply of domestic assets is reduced with the lower investment rate after reforms.

The Appendix proposes another model with price of goods, nominal rigidities, and heterogeneous taxes on consumption between foreign and home goods (via value-added taxes). The main reform that increases consumption is the tax rebate on the domestic consumption of foreign goods. Moreover, we can notice that the government even more uses taxes on consumption as instruments to enhance consumption when nominal rigidities are high. 


\section{References}

Aglietta, M. and G. Bai (2012). La voie chinoise, capitalisme et empire. Odile Jacob, 138-147. 1

Aglietta, M. and Y. Landry (2007). La chine vers la superpuissance. Economica. 14

Albonico, A., S. Kalyvitis, and E. Pappa (2012). Revisiting the Productivity-Hours Puzzle in the RBC Paradigm: The Role of Investment Adjustment Costs. Quaderni di Dipartimento 164, University of Pavia, Department of Economics and Quantitative Methods. 6, 12

Alfaro, L., S. Kalemli-Ozcan, and S. Sayek (2009). Fdi, productivity and financial development. The World Economy 32(1), 111-135. 5

Artus, P. (2016a). Que se passe-t-il si la Chine revient à un modèle économique plus près du modèle communiste traditionnel? Natixis - Recherche Economique - N.252. 1, 14, 21

Artus, P. (2016b). Quelle utilisation pour l'épargne de la Chine ? Natixis - Recherche Economique N.175. 16

Auray, S., B. de Blas, and A. Eyquem (2011). Ramsey policies in a small open economy with sticky prices and capital. Journal of Economic Dynamics and Control 35(9), 1531-1546. 26, 28

Auray, S., A. Eyquem, and P. Gomme (2016). A tale of tax policies in open economies. International Economic Review 57(4), 1299-1333. 14

Backus, D. K., P. J. Kehoe, and F. E. Kydland (1994). Dynamics of the trade balance and the terms of trade: The j-curve? The American Economic Review 84(1), 84-103. 28

Bénassy-Quéré, A., B. Carton, and L. Gauvin (2013). China and global rebalancing: A two-country approach. China Economic Review 26, 118-139. 2, 12, 28

Benhima, K. (2013). Financial integration, capital misallocation and global imbalances. Journal of International Money and Finance 32(C), 324-340. 3

Benigno, G. and P. Benigno (2003). Price stability in open economies. The Review of Economic Studies 70(4), 743-764. 24

Borst, N. and N. Lardy (2015). Maintaining Financial Stability in the People's Republic of China during Financial Liberalization. Peterson Institute for International Economics Working Paper (15-4). 1, 14

Boyreau-Debray, G. (2003). Financial intermediation and growth - Chinese style. Policy Research Working Paper Series 3027, The World Bank. 1, 7

Boyreau-Debray, G. and S.-J. Wei (2005). Pitfalls of a State-Dominated Financial System: The Case of China. NBER Working Papers 11214, National Bureau of Economic Research, Inc. 7

Brandt, L. and X. Zhu (2010). Accounting for China's Growth. IZA Discussion Papers 4764, Institute for the Study of Labor (IZA). 11, 12

Calvo, G. A. (1983). Staggered prices in a utility-maximizing framework. Journal of monetary Economics 12(3), 383-398. 26

Chen, Y., S. Démurger, and M. Fournier (2005). Earnings differentials and ownership structure in chinese enterprises. Economic Development and cultural change 53(4), 933-958. 1

Chen, Z., Y. Ge, and H. Lai (2011). Foreign direct investment and wage inequality: Evidence from china. World Development 39(8), 1322-1332. 1

Christiano, L. J., M. Eichenbaum, and C. L. Evans (2005). Nominal Rigidities and the Dynamic Effects of a Shock to Monetary Policy. Journal of Political Economy 113(1), 1-45. 6

Coeurdacier, N., S. Guibaud, and K. Jin (2015). Credit constraints and growth in a global economy. The American Economic Review 105(9), 2838-2881. 12, 28

Ding, S., J. Knight, and X. Zhang (2016). Does china overinvest? evidence from a panel of chinese firms. The European Journal of Finance, 1-23. 1, 14

Dixit, A. K. and J. E. Stiglitz (1977). Monopolistic competition and optimum product diversity. The American Economic Review 67(3), 297-308. 25

Dollar, D. and S.-J. Wei (2007). Das (Wasted) Kapital: Firm Ownership and Investment Efficiency in China. IMF Working Papers 07/9, International Monetary Fund. 1, 7

Du, J. and S. Girma (2007). Finance and Firm Export in China. Kyklos 60(1), 37-54. 5, 7, 16

Feldstein, M. (2000). Aspects of global economic intergration: Outlook for the future. Technical report, National Bureau of Economic Research. 5 
Fernández-Villaverde, J. and J. F. Rubio-Ramírez (2009). A baseline dsge model. University of Pennsylvania (October). Robert E. Hall 229. 26

Fukumoto, T. and I. Muto (2011). Rebalancing China's Economic Growth: Some Insights from Japan's Experience. Bank of Japan Working Paper Series 11-E-5, Bank of Japan. 1, 2, 16, 21

Funke, M., P. Mihaylovski, and H. Zhu (2015). Monetary policy transmission in China: A DSGE model with parallel shadow banking and interest rate control. BOFIT Discussion Papers 9/2015, Bank of Finland, Institute for Economies in Transition. 7, 12, 28

Groth, C. and H. Khan (2010). Investment Adjustment Costs: An Empirical Assessment. Journal of Money, Credit and Banking 42(8), 1469-1494. 6

Hale, G. and C. Long (2011). Did foreign direct investment put an upward pressure on wages in china? IMF Economic Review 59(3), 404-430. 1

Harrison, A. E. and M. S. McMillan (2003). Does direct foreign investment affect domestic credit constraints? Journal of International Economics 61(1), 73-100. 5

Héricourt, J. and S. Poncet (2009). FDI and credit constraints: Firm-level evidence from China. Economic Systems 33(1), 1-21. 7

Hsieh, C.-T. and Z. M. Song (2015). Grasp the Large, Let Go of the Small: The Transformation of the State Sector in China. NBER Working Papers 21006, National Bureau of Economic Research, Inc. 3, 11,12

IMF (2015). Country Report No. 15/234 (China). 1, 14, 21

Ju, J. and S.-J. Wei (2010). Domestic institutions and the bypass effect of financial globalization. American Economic Journal: Economic Policy 2(4), 173-204. 7

Kimball, D. and F. Xiao (2006). Effectiveness and effects of china's capital controls. Paper presented at the Conference: WTO, China, and the Asian Economies, IV: Economic Integration and Economic Development, University of International Business and Economics, Beijing, China, June 24-25. 4

Krugman, P. (2011). Will China break? The New York Times. 7

Lee, M. I. H., M. M. H. Syed, and M. L. Xueyan (2012). Is China over-investing and does it matter? Number 12-277. International Monetary Fund. 1

Leutert, W. (2016). Challenges ahead in china's reform of state-owned enterprises. asia policy 21(1), 83-99. 21

Li, T. (2014). Shadow banking in China: expanding scale, evolving structure. Journal of Financial Economic Policy 6(3), 198-211. 7

Poncet, S., W. Steingress, and H. Vandenbussche (2010). Financial constraints in China: Firm-level evidence. China Economic Review 21(3), 411-422. 1, 7, 12

Reichling, F. and C. Whalen (2012). Review of Estimates of the Frisch Elasticity of Labor Supply: Working Paper 2012-13. Working Papers 43676, Congressional Budget Office. 12

Rotemberg, J. and M. Woodford (1997). An optimization-based econometric framework for the evaluation of monetary policy. In NBER Macroeconomics Annual 1997, Volume 12, pp. 297-361. MIT Press. 28

Song, Z., K. Storesletten, and F. Zilibotti (2011). Growing like china. American Economic Review 101(1), 196-233. 1, 3, 7, 12

Tsai, K. S. (2002). Back-alley banking: Private entrepreneurs in china. Cornell University Press. 7

Wang, F.-L. (2004). Reformed migration control and new targeted people: China's hukou system in the 2000s. The China Quarterly 177, 115-132. 5

Wang, S. (1997). China's 1994 fiscal reform: an initial assessment. Asian Survey 37(9), 801-817. 1

Whelan, K. (2015). The calvo model of price rigidity. MA Advanced Macro, University College Dublin. 26

Yang, D. T., V. W. Chen, and R. Monarch (2010). Rising wages: Has china lost its global labor advantage? Pacific Economic Review 15(4), 482-504. 1

Zhou, X. (2013). China's Road to Greater Financial Stability: Some Policy Perspectives. Das, Mr Udaibir S and Fiechter, Jonathan and Sun, Tao. International Monetary Fund. 14

Zuo, X. and F. Wang (1999). Inside china's cities: Institutional barriers and opportunities for urban migrants. American Economic Review 89(2), 276-280. 5 


\section{Appendix: An extension with price of goods, nominal rigidi- ties and VATs}

\subsection{The model}

The previous model is extended by adding prices of goods, the consumption of foreign and home goods, the nominal exchange rate and price rigidities. There are still two countries, however, we consider that there is only one type of firm in each country. Indeed, this analysis focuses on the reforms that increase consumption, on taxes on consumption (VATs) of home and foreign goods, but not on the characteristics of each firm and their investment rate.

Households. Household budget constraint becomes as follows:

$$
p_{c, t} C_{t}\left(1+\tau_{C}\right)+B_{d, t}+\frac{F A_{d, t+1}}{\left(1+r_{f, t+1}\right)}=\pi_{d, t}+F A_{d, t}+\left(1+r_{d, t}\right)\left(1-\gamma_{d}\right) B_{d, t-1}+W_{d, t} N_{d, t}
$$

where $p_{c, t}$ denotes the consumption price index (CPI). Household incomes, $W_{d, t} N_{d, t}$, are partly consumed and $C_{t}$ denotes the global consumption index (consumption of domestic and foreign goods). Households save utilizing bonds; they can choose between bonds issued by firms of the domestic country, $B_{d, t},{ }^{24}$ and $F A_{d, t}$, which is a portfolio of state contingent assets in this framework (in consumption units, first assuming that financial markets are complete). Considering that firms belong to households, their profits $\pi_{d, t}$ are redistributed to households.

Taxation. The tax on returns on bonds $\left(\gamma_{d}\right)$ is maintained, and a tax on consumption $\tau_{C}$ (VAT) is added. The goal of the latter is twofold. First, this tax allows for a heterogeneous taxation between the domestic consumption of home and foreign goods $\left(\tau_{C_{d}} p_{t} C_{d, t}\right.$ and $\tau_{C_{f}} \varepsilon_{t} p_{t}^{*} C_{f, t}$, respectively) and the exports of domestic goods $\left(\tau_{C_{d}^{*}} p_{t} C_{d, t}^{*}\right)$. Second, it enables to adjust consumption by another method than taxes on household incomes, firms' production or taxes on financial transactions.

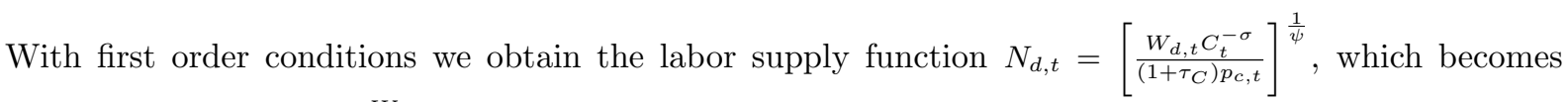
(with real wages $\left.w_{d, t}=\frac{W_{d, t}}{p_{t}}\right)$ :

$$
N_{d, t}=\left[\frac{w_{d, t} p_{t} C_{t}^{-\sigma}}{\left(1+\tau_{C}\right) p_{c, t}}\right]^{\frac{1}{\psi}}
$$

The Euler equation is $\frac{C_{t}^{-\sigma} \Pi_{c, t+1}}{1+\tau_{C}}=\beta E_{t}\left[C_{t+1}^{-\sigma}\left(1+r_{d, t+1}\right)\left(1-\gamma_{d}\right)\right]$ with $\Pi_{c, t}=\frac{p_{c, t}}{p_{c, t-1}}$ the inflation dynamic for consumer prices (see Equation 60).

As in Benigno and Benigno (2003), a continuum of goods are produced in the two countries (indexed on the interval $[0, \mathrm{n}]$ in the domestic country and on $] \mathrm{n}, 1]$ in the foreign country): ${ }^{25}$

$$
\begin{gathered}
C_{t}=\left(h^{\frac{1}{\varphi}} C_{d, t}^{\frac{\varphi-1}{\varphi}}+(1-h)^{\frac{1}{\varphi}} C_{f, t}^{\frac{\varphi-1}{\varphi}}\right)^{\frac{\varphi}{\varphi-1}} \\
C_{t}^{*}=\left(h^{* \frac{1}{\varphi}} C_{d, t}^{* \frac{\varphi-1}{\varphi}}+\left(1-h^{*}\right)^{\frac{1}{\varphi}} C_{f, t}^{* \frac{\varphi-1}{\varphi}}\right)^{\frac{\varphi}{\varphi-1}}
\end{gathered}
$$

\footnotetext{
${ }^{24}$ As explained below, the bonds market clearing condition force $B_{d, t}=D_{d, t}$ (the purchase of bonds by households is equal to the amount firms borrow at time $t$ ) and thus $B_{d, t}=\zeta_{d} p_{t} k_{d, t}$ because firms face credit constraints.

${ }^{25}$ The population size of economic agents in each country is a continuum with set equal to the range of produced goods: domestic households lie on the interval $[0, \mathrm{n}]$ and foreign ones on $] \mathrm{n}, 1]$.
} 
where $C_{d, t}$ and $C_{f, t}$ (respectively, $C_{d, t}^{*}$ and $C_{f, t}^{*}$ ) are consumption of domestic and foreign goods by domestic (respectively, foreign) households. In these expressions $\varphi>1$ is the elasticity of substitution between domestic and foreign goods, and $\theta>1$ the elasticity of substitution across goods produced within a country. $C_{d, t}, C_{f, t}, C_{d, t}^{*}$, and $C_{f, t}^{*}$ are standard Dixit and Stiglitz (1977) consumption subindexes:

$$
\begin{array}{ll}
C_{d, t}=\left[\left(\frac{1}{n}\right)^{\frac{1}{\theta}} \int_{0}^{n} C_{d, t}(i)^{\frac{\theta-1}{\theta}} d i\right]^{\frac{\theta}{\theta-1}}, & C_{f, t}=\left[\left(\frac{1}{1-n}\right)^{\frac{1}{\theta}} \int_{n}^{1} C_{f, t}(i)^{\frac{\theta-1}{\theta}} d i\right]^{\frac{\theta}{\theta-1}} \\
C_{d, t}^{*}=\left[\left(\frac{1}{n}\right)^{\frac{1}{\theta}} \int_{0}^{n} C_{d, t}^{*}(i)^{\frac{\theta-1}{\theta}} d i\right]^{\frac{\theta}{\theta-1}}, & C_{f, t}^{*}=\left[\left(\frac{1}{1-n}\right)^{\frac{1}{\theta}} \int_{n}^{1} C_{f, t}^{*}(i)^{\frac{\theta-1}{\theta}} d i\right]^{\frac{\theta}{\theta-1}}
\end{array}
$$

All goods are traded and the law of one price holds, with $\varepsilon_{t}$ the nominal exchange rate defined as the price of the foreign currency in terms of domestic currency. Thus, consumption prices are (with $h$ and $h^{*}$ the home biases in the domestic and foreign countries, respectively):

$$
\begin{gathered}
p_{c, t}=\left(h p_{t}^{1-\varphi}+(1-h)\left(\varepsilon_{t} p_{t}^{*}\right)^{1-\varphi}\right)^{\frac{1}{1-\varphi}} \\
p_{c, t}^{*}=\left(h^{*}\left(\varepsilon_{t}^{-1} p_{t}\right)^{1-\varphi}+\left(1-h^{*}\right) p_{t}^{* 1-\varphi}\right)^{\frac{1}{1-\varphi}}
\end{gathered}
$$

and production prices:

$$
p_{t}=\left[\left(\frac{1}{n}\right) \int_{0}^{n} p_{t}(i)^{1-\theta} d i\right]^{\frac{1}{1-\theta}}, \quad p_{t}^{*}=\left[\left(\frac{1}{1-n}\right) \int_{n}^{1} p_{t}(i)^{1-\theta} d i\right]^{\frac{1}{1-\theta}} .
$$

The terms of trade $s_{t}$ are defined as a function of the nominal exchange rate:

$$
s_{t}=\varepsilon_{t} \frac{p_{t}^{*}}{p_{t}}
$$

with the real exchange rate $\varepsilon_{r, t}=\varepsilon_{t} \frac{p_{c, t}^{*}}{p_{c, t}}=$ and $\varepsilon_{r, t} \frac{s_{t}}{s_{t-1}} \frac{\Pi_{t}}{\Pi_{t}^{*}}=1$.

First assuming that financial markets (of state contingent assets in consumption units) are complete, the risk sharing condition is obtained combining both domestic and foreign Euler conditions:

$$
\frac{U_{c, t}^{*}}{U_{c, t}}=\frac{\lambda_{f, t}}{\lambda_{d, t}}=\Psi \varepsilon_{t} \frac{p_{c, t}^{*}}{p_{c, t}}=\Psi\left(\frac{h^{*}+\left(1-h^{*}\right) s_{t}^{1-\varphi}}{h+(1-h) s_{t-1}^{1-\varphi}}\right)^{\frac{1}{1-\varphi}}
$$

with $\Psi$ the initial condition on net foreign assets.

The demands of goods $\mathrm{d}$ and $\mathrm{f}$ are given by:

$$
\begin{aligned}
& C_{d, t}(i)=\frac{h}{n} \cdot\left(\frac{p_{t}(i)}{p_{t}}\right)^{-\theta}\left(\frac{p_{t}}{p_{c, t}}\right)^{-\varphi} C_{t}(i), \quad C_{d, t}^{*}(i)=\frac{1-h^{*}}{1-n} \cdot\left(\frac{p_{t}(i)}{p_{t}}\right)^{-\theta}\left(\frac{p_{t}}{\varepsilon_{t} p_{c, t}^{*}}\right)^{-\varphi} C_{t}(i)^{*} \\
& C_{f, t}(i)=\frac{1-h}{n} \cdot\left(\frac{p_{t}^{*}(i)}{p_{t}^{*}}\right)^{-\theta}\left(\frac{\varepsilon_{t} p_{t}^{*}}{p_{c, t}}\right)^{-\varphi} C_{t}(i), \quad C_{f, t}^{*}(i)=\frac{h^{*}}{1-n} \cdot\left(\frac{p_{t}^{*}(i)}{p_{t}^{*}}\right)^{-\theta}\left(\frac{p_{t}^{*}}{p_{c, t}^{*}}\right)^{-\varphi} C_{t}(i)^{*}
\end{aligned}
$$

When combined with 43, 44, and 46, they become:

$$
C_{d, t}=h\left[h+(1-h) s_{t}^{1-\varphi}\right]^{\frac{\varphi}{1-\varphi}} C_{t}, \quad C_{d, t}^{*}=\left(1-h^{*}\right) s_{t}^{\varphi}\left[\left(1-h^{*}\right)+h^{*} s_{t}^{\varphi-1}\right]^{\frac{\varphi}{1-\varphi}} C_{t}^{*}
$$




$$
C_{f, t}=(1-h) s_{t}^{-\varphi}\left[h+(1-h) s_{t}^{1-\varphi}\right]^{\frac{\varphi}{1-\varphi}} C_{t}, \quad C_{f, t}^{*}=h^{*}\left[\left(1-h^{*}\right)+h^{*} s_{t}^{\varphi-1}\right]^{\frac{\varphi}{1-\varphi}} C_{t}^{*}
$$

Firms. The structure of firms is simplified with one type of firm in each country, the taxes on production $\left(\tau_{y_{d}}\right)$ and on labor costs $\left(\tau_{w_{d}}\right)$ that were applied in the previous model are maintained, and production prices are considered. $p_{t}$ denotes the production price index (PPI) in the domestic country, which is set with Calvo (1983) pricing contracts. Firms' profits become as follows:

$$
\pi_{d, t}=p_{t} y_{d, t}\left(1-\tau_{y d}\right)+D_{d, t}-\left(1+r_{d, t}\right)\left(1-\gamma_{d}\right) D_{d, t-1}-\left(W_{d, t} N_{d, t}\left(1+\tau_{w_{d}}\right)+p_{t} i_{d, t}\right)
$$

with credit constraints $D_{d, t}=\zeta_{d} p_{t} k_{d, t}$. The law of motion of capital comprises adjustment costs $\left(k_{d, t}=\right.$ $\left.\left(1-\delta_{d}\right) k_{d, t-1}+i_{d, t}+i_{d, t-1} \Phi_{I}\left[\frac{i_{d, t}}{i_{d, t-1}}-1\right]^{2}\right)$ and aggregate production utilizes a standard Cobb-Douglas technology: $\quad y_{d, t} \Upsilon_{t}=\left(A_{d, 0}+A_{d, t}\right) \cdot k_{d, t-1}^{\alpha_{d}} N_{d, t}^{1-\alpha_{d}}$ with $A_{d, t}=\rho_{A} A_{d, t-1}+\xi$ an i.d.d. productivity shock with constant variance. Contrary to the previous model, TFP growth is not modeled because the balanced growth path cannot be computed with the definition of marginal costs in Equation 55. $\Upsilon_{t}$ is the price dispersion (Equation 61), which is defined below with the Calvo pricing.

The first order condition with respect to labor demand gives the efficiency conditions for input prices:

$$
\alpha_{d} w_{d, t} N_{d, t}\left(1+\tau_{w_{d}}\right)=\left(1-\alpha_{d}\right) m p K_{d, t} k_{d, t-1}
$$

with $m p K_{d, t}=\alpha_{d} \frac{y_{d, t+1}\left(1-\tau_{y_{d}}\right)}{k_{d, t}}$ (considering the real output defined as $y_{d, t}=\frac{Y_{d, t}}{p_{t}}$ ). Then, we obtain real marginal costs:

$$
m c_{d, t}=\frac{m p K_{d, t}^{\alpha_{d}}\left(w_{d, t}\left(1+\tau_{w_{d}}\right)\right)^{1-\alpha_{d}}}{\alpha_{d}^{\alpha_{d}}\left(1-\alpha_{d}\right)^{1-\alpha_{d}}\left(A_{d, 0}+A_{d, t}\right)}
$$

Firms set their production prices with Calvo (1983) pricing contracts. Only a fraction $1-\eta$ of randomly selected firms is allowed to set new prices in each period:

$$
p_{t}=\left[(1-\eta) \bar{p}_{t}^{1-\theta}+\eta p_{t-1}^{1-\theta}\right]^{\frac{1}{1-\theta}}
$$

Firms select their optimal reset price to maximize the expected present discounted values of real profits all along their price contract (Fernández-Villaverde and Rubio-Ramírez, 2009, Auray et al., 2011, and Whelan, 2015), and then obtain the first-order condition:

$$
\bar{p}_{d, t}=\frac{\theta}{(1-\theta)\left(1-\tau_{y_{d}}\right)} \frac{\sum_{\tau=0}^{\infty}(\eta)^{\tau} E_{t}\left\{\lambda_{t+\tau} y_{d, t+\tau} m c_{d, t+\tau}\right\}}{\sum_{\tau=0}^{\infty}\left(\beta_{d} \eta\right)^{\tau} E_{t}\left\{y_{d, t+\tau}\right\}}
$$

After recursive transformations we obtain:

$$
\begin{aligned}
\tau_{1, t}-\beta \eta E_{t}\left\{\tau_{1, t+1} \Pi_{t+1}^{1+\theta} \Pi_{c, t+1}^{-1}\right\} & =C_{t}^{-\sigma} y_{d, t} m c_{d, t} \\
\tau_{2, t}-\beta \eta E_{t}\left\{\tau_{2, t+1} \Pi_{t+1}^{\theta} \Pi_{c, t+1}^{-1}\right\} & =C_{t}^{-\sigma} y_{d, t}
\end{aligned}
$$


where $\Pi_{t}=\frac{p_{t}}{p_{t-1}}$ is the inflation dynamic for production prices:

$$
\eta \Pi_{t}^{\theta-1}+(1-\eta)\left(\frac{\theta}{(\theta-1)\left(1-\tau_{y_{d}}\right)} \frac{\tau_{1, t}}{\tau_{2, t}}\right)^{1-\theta}=1
$$

and $\Pi_{c, t}=\frac{p_{c, t}}{p_{c, t-1}}$ is the inflation dynamic for consumer prices (which is obtained combining Equations 43 and 46$)$ :

$$
\Pi_{c, t}=\Pi_{t}\left(\frac{h+(1-h) s_{t}^{1-\varphi}}{h+(1-h) s_{t-1}^{1-\varphi}}\right) .
$$

The price dispersion (which appears in the production function) is obtained with Equations 43,46 and 59 :

$$
\Upsilon_{t}=\eta \Upsilon_{t-1} \Pi_{t}^{\theta}+(1-\eta)\left(\frac{\theta}{(\theta-1)\left(1-\tau_{y_{d}}\right)} \frac{\tau_{1, t}}{\tau_{2, t}}\right)^{-\theta} .
$$

Equilibrium. The bonds market clearing condition forces $B_{d, t}=D_{d, t}$ (the purchase of bonds by households is equal to the amount firms borrow at time $t$ ) and thus $B_{d, t}=\zeta_{d} p_{t} k_{d, t}$ because firms face credit constraints. Then, both domestic and foreign governments collect their revenue from firms' production, wages, loan repayments and consumption through the set of taxes. For simplicity and because there are already many different types of bonds, it is assumed that the governments do not use domestic or foreign bonds to finance potential deficits. The government use fiscal receipts to finance public expenditure on the goods and services markets:

$$
\begin{aligned}
y_{d, t} & =C_{d, t}+C_{f, t}+G_{d, t}+i_{d, t} \\
& =\left[h+(1-h) s_{t}^{-\varphi}\right]\left[h+(1-h) s_{t}^{1-\varphi}\right]^{\frac{\varphi}{1-\varphi}} C_{t}+G_{d, t}+i_{d, t} \\
y_{f, t} & =C_{d, t}^{*}+C_{f, t}^{*}+G_{f, t}+i_{f, t} \\
& =\left[h^{*}+\left(1-h^{*}\right) s_{t}^{\varphi}\right]\left[\left(1-h^{*}\right)+h^{*} s_{t}^{\varphi-1}\right]^{\frac{\varphi}{1-\varphi}} C_{t}^{*}+G_{f, t}+i_{f, t}
\end{aligned}
$$

\subsection{Calibration}

Similar to the previous calibration in Subsection 2.4, we target, at the initial steady state, a high investment rate (close to $40 \%$ in this model) and a low consumption rate (approximately $39 \%$ ), which are close to the 2014-2017 data.

The calibration of the new parameters of this second model follows the literature on China and on twocountry models with nominal rigidities, and the calibration of the previous model.

Concerning taxation, the initial value of VAT on the domestic consumptions of home and foreign goods $\left(\tau_{C_{d}}\right.$ and $\tau_{C_{f}}$, respectively) is initially set at 0.17 (see Figure 7, Source: State Administration of Taxation of the People's Republic of China), and VAT on exports of domestic goods $\left(\tau_{C_{d}}^{*}\right)$ is initially nil (because of tax rebates, Source: State Administration of Taxation of the People's Republic of China). The initial calibration of the other taxes is similar to the previous model, that is, $\tau_{y, 0}=0.0197$ for the tax on firms' production/business tax (Source: CSY and author's calculations: it is a weighted mean of all types of firms and all sectors), $\tau_{w, 0}=0.29$ for the social security contributions (Sources: State Administration of Taxation of the People's Republic of China, social insurance law ("China Labour Bulletin") and "China Taxation and Investment 2016" (Deloitte)) and $\gamma_{0}=0.03$ for the financial transaction tax (to match a $3 \%$ real deposit rate). 


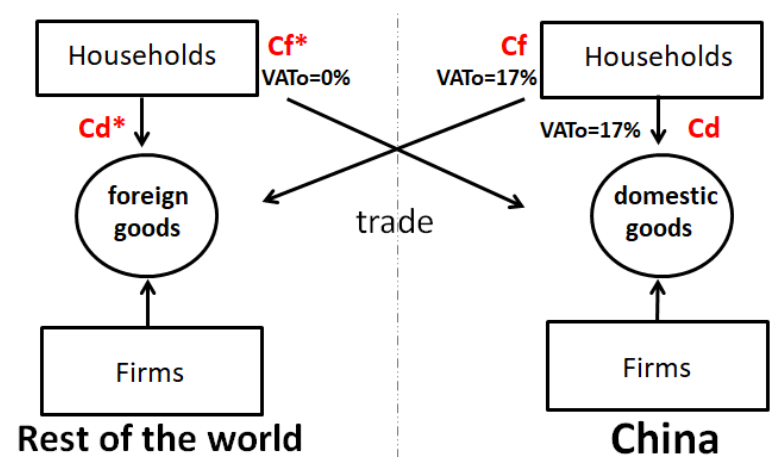

Figure 7: Taxes on the consumptions of domestic and foreign goods

Regarding nominal rigidities, we set the price rigidity parameter $\eta$ at 0.55 in China for the benchmark calibration; this value goes up to 0.65 during certain reforms (which is close to Bénassy-Quéré et al., 2013, where $\eta=0.67$ in China).

As for preferences, the elasticity of substitution across domestic goods is set at 7 (close to the calibration of Funke et al., 2015, and as in Rotemberg and Woodford, 1997, and Bénassy-Quéré et al., 2013), the elasticity of substitution between domestic and foreign goods is fixed at 1.5 (as in Backus et al., 1994, and Auray et al., 2011), and the share of imports in China's consumption is equal to 0.2 (Bénassy-Quéré et al., 2013). The households' intertemporal elasticity of substitution is equal to that of Funke et al. (2015), that is, 1.

Concerning firms, the capital share $\alpha_{d}$ and the depreciation rate of capital $\delta_{d}$ are fixed at 0.6 (to reach the highest investment rate possible in the model) and 0.14 (close to Funke et al., 2015), respectively. The initial level of technology remains equal to $53 \%$ of the most developed countries level (Source: St Louis Fed Stats and author's calculations), and credit constraints are more relaxed than those in Coeurdacier et al. (2015). Indeed, in this second model, there is only one type of firm, which thus comprises both SOEs (which are well financed by state-owned banks) and private firms (which can benefit from alternative finance).

\subsection{Tax reforms}

In this analysis, we focus on the reforms that target a higher consumption ratio (at least $50 \%$ of GDP), and on the heterogeneous taxation of home and foreign goods' consumption. The instruments of the reforms are VATs on the domestic consumption of home $\left(\tau_{C_{d}}\right)$ and foreign goods $\left(\tau_{C_{f}}\right)$, VAT on the exports of the domestic good $\left(\tau_{C_{d}^{*}}\right)$, and also taxes on firms' production $\left(\tau_{y}\right)$, household incomes $\left(\tau_{w}\right)$ and on financial transactions $(\gamma)$. During the reform each tax follows a first-order autoregressive process: $\tau_{t}=\rho_{\tau} \tau_{t-1}+\left(1-\rho_{\tau}\right) \bar{\tau}$, where $\bar{\tau}$ is the tax value at the final steady state of the reform.

\begin{tabular}{lc|ccc}
\hline \hline & Price rigidities & $\eta=0.55$ & $\eta=0.6$ & $\eta=0.65$ \\
Taxes & Initial & Reform & Reform & Reform \\
& & & & \\
$\tau_{y}$ & 0.0197 & 0.0353 & 0.0413 & 0.0446 \\
$\tau_{w}$ & 0.29 & 0.3404 & 0.3485 & 0.4613 \\
$\gamma$ & 0.03 & 0.0227 & 0.0161 & 0.0287 \\
$\tau_{C_{d}}$ & 0.17 & 0.1668 & 0.1290 & 0.1376 \\
$\tau_{C_{f}}$ & 0.17 & 0.1812 & 0.1675 & 0.1089 \\
$\tau_{C_{d}^{*}}$ & 0 & 0.0001 & 0.0000 & -0.0024 \\
\hline \hline
\end{tabular}

Table 6: Taxes and price rigidities - Consumption reform ( $>50 \%$ of GDP) 
The results in Table 6 give some insights about the methods the government can use to raise consumption while maintaining sufficient fiscal receipts. In this framework, the government operates through two channels to reach a higher consumption ratio.

First, the same channel than in the previous model is used: returns on bonds. Indeed, $\gamma$ is lower, which raises returns on household bonds $\left(\Delta_{-} \gamma_{d, t} \Rightarrow \Delta_{+} r_{d, t}\left(1-\gamma_{d}\right)\right)$. Thus, household income and consumption increase through wealth effect (the utility function, $\log \left(c_{t}\right)-\frac{N_{d, t}^{1+\psi}}{1+\psi}$, allows for a strong wealth effect). The second channel through which the government raises consumption in this framework is consumption taxes. Indeed, during tax reforms the consumption of home and foreign imported goods is often less taxed than in the initial steady state $\left(\tau_{C_{d / f}}<0.17\right.$, Table 6$)$. This decrease in consumption taxes is stronger when nominal rigidities are high: when inflation cannot be adjusted downward, the government may lower taxes on domestic consumption of foreign and home goods. We can also observe that VAT on foreign imported goods declines more than VAT on home goods when nominal rigidities are high. Indeed, a strong reduction in $\tau_{C_{f}}$ directly offsets the losses due to higher foreign prices and thus enhances consumption. Moreover, the exchange rate is flexible in this study, so the purchasing power of households for foreign goods is enhanced compared to a pegged and undervalued exchange rate.

The two channels through which the government raises consumption, VATs $\left(\tau_{C_{d}}\right.$ and $\left.\tau_{C_{f}}\right)$ and the tax on bonds' returns $(\gamma)$, interact with each other: when VATs strongly decrease, $\gamma$ returns to its initial value (Table 6 , reform with $\eta=0.65$ ). As a matter of fact, low VATs are more effective under high price rigidities and the corresponding rise in $\gamma$ is a means to maintain sufficient fiscal receipts. Another point is that surprisingly, the government does not use the tax on firms' production to impact consumption. Indeed, in this theoretical framework, firms belong to households. Therefore, looser taxes on firms' production would directly increase household income. An explanation is that the government uses taxes on firms' production and labor cost to compensate the drop in VATs and/or in the financial transactions $\operatorname{tax}\left(\tau_{y}\right.$ and $\tau_{w}$ significantly increase when $\tau_{C_{d / f}}$ or $\gamma$ decrease).

Finally, these reforms confirm the fact that VAT rebates on exports $\left(\tau_{C_{f}}^{*}=0\right)$ is a key tool to maintain low prices on exported home goods. Moreover, these VAT rebates on exports have a negative effect on the production price of home goods, which slows the inflation dynamic of domestic consumer prices between the two steady states. 